Prepared in cooperation with the U.S. Environmental Protection Agency

\title{
Geophysical Log Analysis of Selected Test and Residential Wells at the Shenandoah Road National Superfund Site, East Fishkill, Dutchess County, New York
}

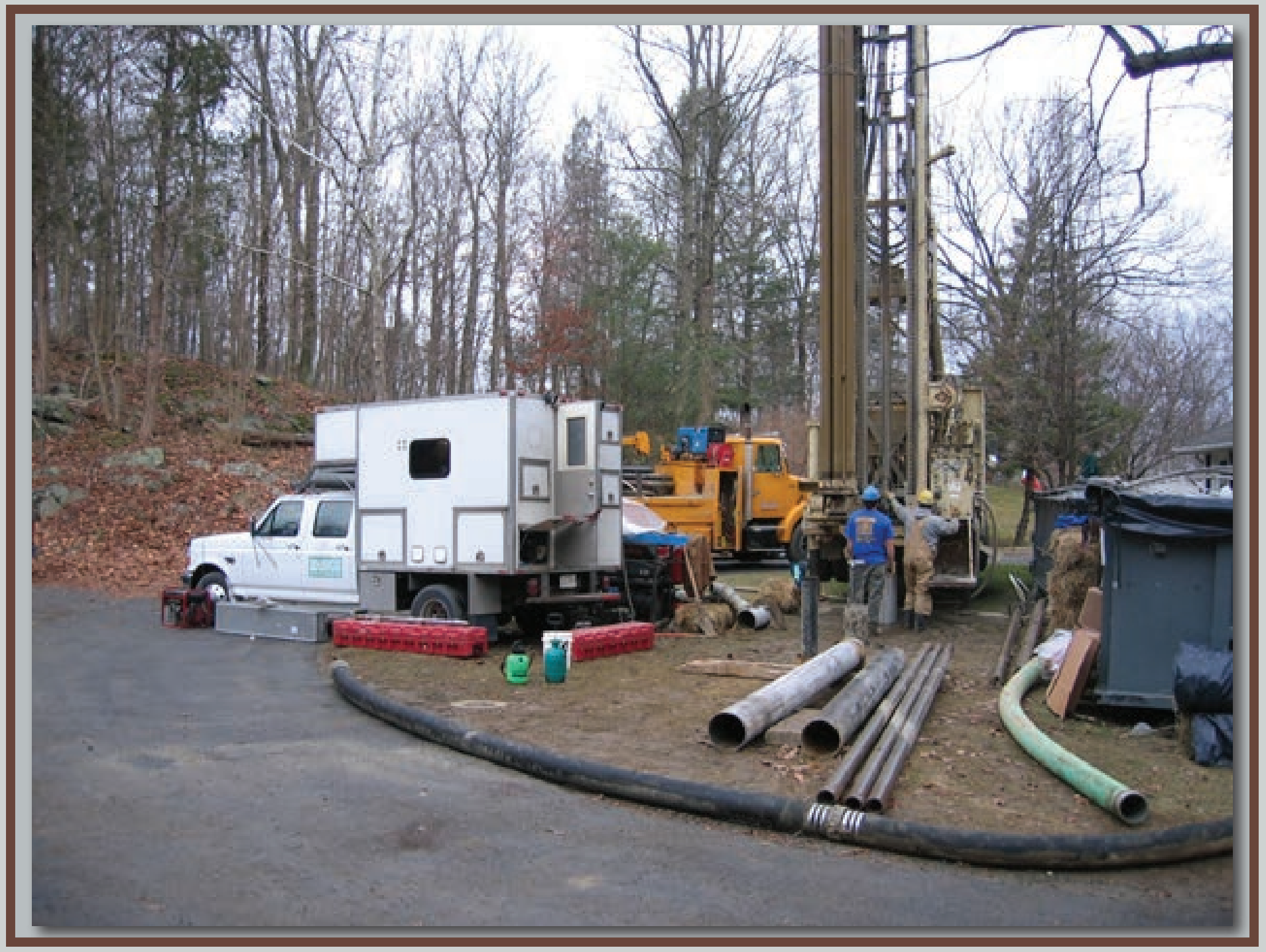

Scientific Investigations Report 2014-5228

U.S. Department of the Interior

U.S. Geological Survey 
Cover. Drilling well SRMW-18D at the Shenandoah Road National Superfund Site. Geophysical logging of adjacent well SRMW-18B is being conducted during air rotary drilling of SRMW-18D. 


\section{Geophysical Log Analysis of Selected Test and Residential Wells at the Shenandoah Road National Superfund Site, East Fishkill, Dutchess County, New York}

By Richard J. Reynolds, J. Alton Anderson, and John H. Williams

Prepared in cooperation with the U.S. Environmental Protection Agency

Scientific Investigations Report 2014-5228 


\title{
U.S. Department of the Interior SALLY JEWELL, Secretary
}

\section{U.S. Geological Survey Suzette M. Kimball, Acting Director}

\author{
U.S. Geological Survey, Reston, Virginia: 2015
}

For more information on the USGS - the Federal source for science about the Earth, its natural and living resources, natural hazards, and the environment, visit http://www.usgs.gov or call 1-888-ASK-USGS.

For an overview of USGS information products, including maps, imagery, and publications, visit http://www.usgs.gov/pubprod

To order this and other USGS information products, visit http://store.usgs.gov

Any use of trade, firm, or product names is for descriptive purposes only and does not imply endorsement by the U.S. Government.

Although this information product, for the most part, is in the public domain, it also may contain copyrighted materials as noted in the text. Permission to reproduce copyrighted items must be secured from the copyright owner.

Suggested citation:

Reynolds, R.J., Anderson, J.A., and Williams, J.H., 2015, Geophysical log analysis of selected test and residential wells at the Shenandoah Road National Superfund Site, East Fishkill, Dutchess County, New York: U.S. Geological Survey Scientific Investigations Report 2014-5228, 30 p., http://dx.doi.org/10.3133/sir20145228 


\section{Acknowledgments}

The authors thank Damian Duda of the U.S. Environmental Protection Agency, Region 2, and Grant Anderson of the U.S. Army Corps of Engineers for supporting the U.S. Geological Survey technical role in this investigation. Craig Robertson, Dorothy Bergmann, and Mitch Ruchin of Groundwater Sciences Corporation and their staff are thanked for their assistance in the geophysical logging operations. 



\section{Contents}

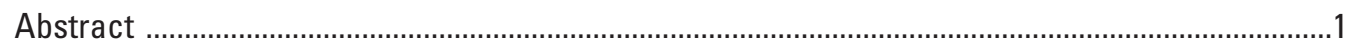

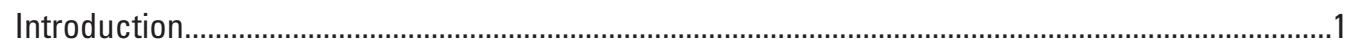

Description of Study Area ..........................................................................................................2

Remedial Investigation of the Shenandoah Road National Superfund Site ..............................2

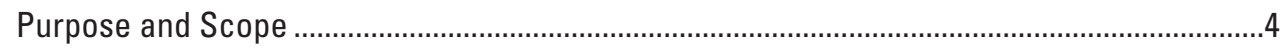

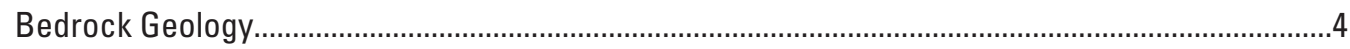

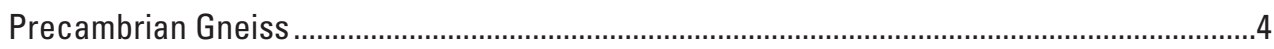

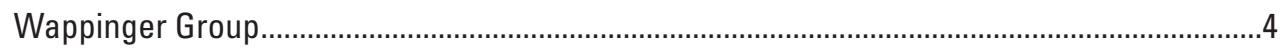

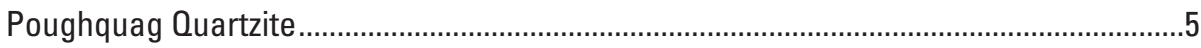

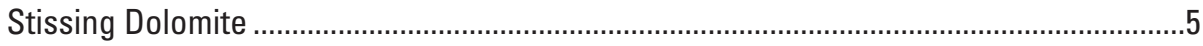

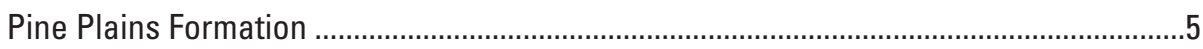

Briarcliff Dolomite................................................................................................... 5

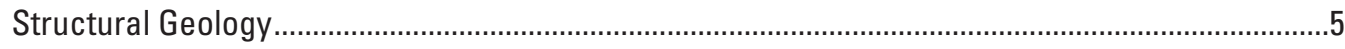

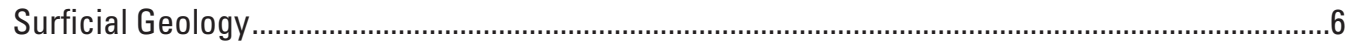

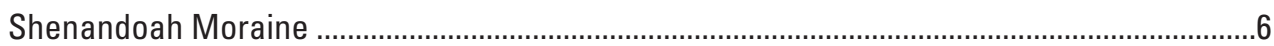

Outwash Sand and Gravel.............................................................................................

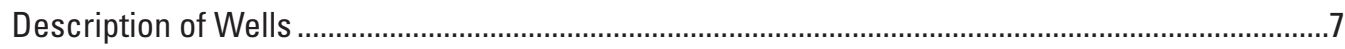

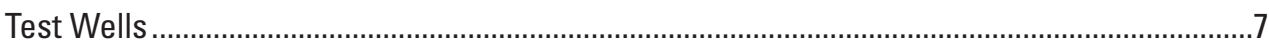

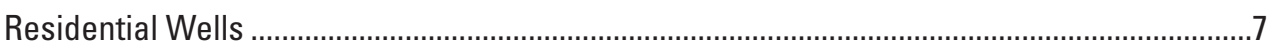

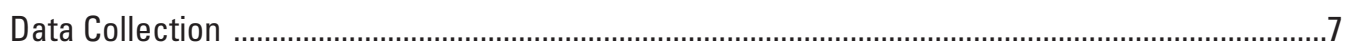

Drilling Logs for Test Wells...................................................................................................

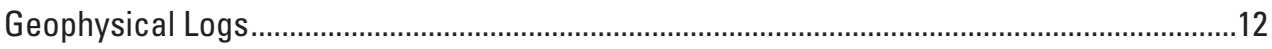

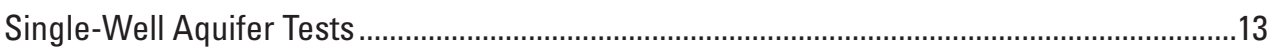

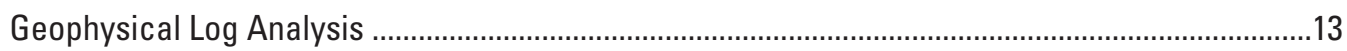

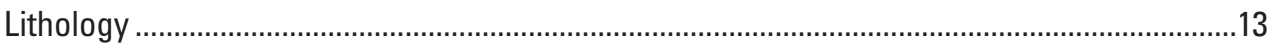

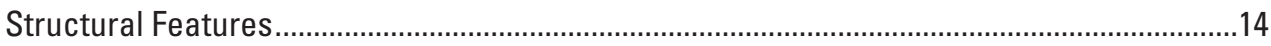

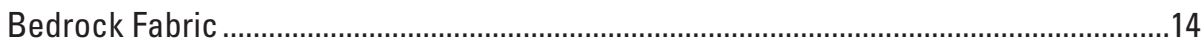

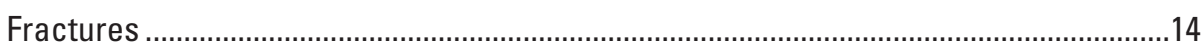

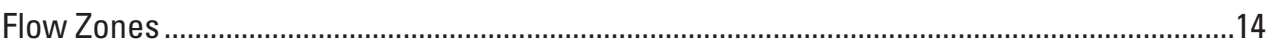

Distribution of Flow Zones and Wellbore Flow .....................................................................14

Estimates of Total Wellbore Transmissivity ...............................................................................15

Estimates of Flow-Zone Transmissivity and Head .....................................................................15

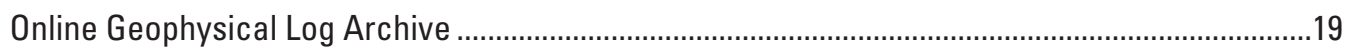

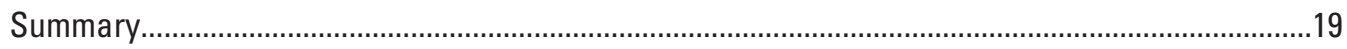

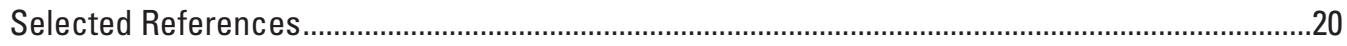

Appendix 1. Geophysical Log Analysis of Three Selected Wells at the Shenandoah Road National Superfund Site, Dutchess County, N.Y.................................................................23

Explanation of Geophysical Log Column Headings ..................................................................30 


\section{Figures}

1. Map showing location of logged wells at the Shenandoah Road National Superfund Site, Dutchess County, N.Y.

2. Log-Log plot of specific capacity at 30 minutes versus transmissivity for logged wells at the Shenandoah Road National Superfund Site, Dutchess County, N.Y.

3. Conceptual model of two flow zones in a well with heads under ambient and pumped conditions...

4. Graph showing frequency distribution of estimated transmissivity of flow zones penetrated by wells at the Shenandoah Road National Superfund Site, Dutchess County, N.Y.

5. Graph showing depths of individual fracture zones versus estimated fracture zone transmissivity for wells logged at the Shenandoah Road National Superfund Site, Dutchess County, N.Y.

6. Graph showing comparison of estimated hydraulic-head difference to measured hydraulic-head difference for flow zones in logged wells at the Shenandoah Road National Superfund Site, Dutchess County, N.Y.

\section{Tables}

1. Location, construction, and water-level information for selected wells at the Shenandoah Road National Superfund Site, Dutchess County, N.Y

2. Types of geophysical logs collected from selected wells at the Shenandoah Road National Superfund Site, Dutchess County, N.Y

3. Ambient water levels, pumping rates, specific capacities, and transmissivities for selected wells at the Shenandoah Road National Superfund Site,

Dutchess County, N.Y. 


\section{Conversion Factors and Datum}

\begin{tabular}{|c|c|c|}
\hline Multiply & By & To obtain \\
\hline \multicolumn{3}{|c|}{ Length } \\
\hline inch (in.) & 2.54 & centimeter $(\mathrm{cm})$ \\
\hline inch (in.) & 25.4 & millimeter $(\mathrm{mm})$ \\
\hline foot $(\mathrm{ft})$ & 0.3048 & meter $(\mathrm{m})$ \\
\hline mile (mi) & 1.609 & kilometer $(\mathrm{km})$ \\
\hline \multicolumn{3}{|c|}{ Area } \\
\hline acre & 4,047 & square meter $\left(\mathrm{m}^{2}\right)$ \\
\hline acre & 0.4047 & hectare (ha) \\
\hline \multicolumn{3}{|c|}{ Volume } \\
\hline gallon (gal) & 3.785 & liter $(\mathrm{L})$ \\
\hline \multicolumn{3}{|c|}{ Flow rate } \\
\hline gallon per minute (gal/min) & 0.06309 & liter per second $(\mathrm{L} / \mathrm{s})$ \\
\hline \multicolumn{3}{|c|}{ Specific capacity } \\
\hline $\begin{array}{l}\text { gallon per minute per foot } \\
\qquad[(\mathrm{gal} / \mathrm{min}) / \mathrm{ft})]\end{array}$ & 0.2070 & liter per second per meter $[(\mathrm{L} / \mathrm{s}) / \mathrm{m}]$ \\
\hline \multicolumn{3}{|c|}{ Transmissivity* } \\
\hline foot squared per day $\left(\mathrm{ft}^{2} / \mathrm{d}\right)$ & 0.09290 & meter squared per day $\left(\mathrm{m}^{2} / \mathrm{d}\right)$ \\
\hline
\end{tabular}

Temperature in degrees Celsius $\left({ }^{\circ} \mathrm{C}\right)$ may be converted to degrees Fahrenheit $\left({ }^{\circ} \mathrm{F}\right)$ as follows:

${ }^{\circ} \mathrm{F}=\left(1.8 x^{\circ} \mathrm{C}\right)+32$

Vertical coordinate information is referenced to the North American Vertical Datum of 1988 (NAVD 88).

Horizontal coordinate information is referenced to North American Datum of 1983 (NAD 83).

Altitude, as used in this report, refers to distance above the vertical datum.

*Transmissivity: The standard unit for transmissivity is cubic foot per day per square foot times foot of aquifer thickness $\left[\left(\mathrm{ft}^{3} / \mathrm{d}\right) / \mathrm{ft}^{2}\right] \mathrm{ft}$. In this report, the mathematically reduced form, foot squared per day $\left(\mathrm{ft}^{2} / \mathrm{d}\right)$, is used for convenience.

Specific conductance is given in microsiemens per centimeter at 25 degrees Celsius $(\mu \mathrm{S} / \mathrm{cm}$ at $\left.25^{\circ} \mathrm{C}\right)$.

Concentrations of chemical constituents in water are given either in milligrams per liter (mg/L) or micrograms per liter $(\mu \mathrm{g} / \mathrm{L})$. 


\section{Abbreviations}

\begin{tabular}{ll} 
AOC & Administrative Order on Consent \\
ATV & acoustic televiewer \\
BP & before present \\
EPA & U.S. Environmental Protection Agency \\
ESI & Expanded Site Inspection \\
GSC & Groundwater Sciences Corporation \\
HPFM & heat-pulse flow meter \\
MCL & maximum contaminant levels \\
NYSDEC & New York State Department of Environmental Conservation \\
NYSDOH & New York State Department of Health \\
OTV & optical televiewer \\
PCE & tetrachloroethene \\
POET & point-of-entry-treatment \\
ppb & parts per billion \\
TCE & trichloroethane \\
PRP & potentially responsible party \\
RI/FS & Remedial Investigation/Feasibility Study \\
USGS & U.S. Geological Survey \\
VOC & volatile organic compound \\
& \\
\hline
\end{tabular}




\title{
Geophysical Log Analysis of Selected Test and Residential Wells at the Shenandoah Road National Superfund Site, East Fishkill, Dutchess County, New York
}

\author{
By Richard J. Reynolds, J. Alton Anderson, and John H. Williams
}

\section{Abstract}

The U.S. Geological Survey collected and analyzed geophysical logs from 20 test wells and 23 residential wells at the Shenandoah Road National Superfund Site in East Fishkill, New York, from 2006 through 2010 as part of an Interagency Agreement to provide hydrogeologic technical support to the U.S. Environmental Protection Agency, Region 2. The geophysical logs collected include caliper, gamma, acoustic and optical televiewer, deviation, electromagnetic-induction, magnetic-susceptibility, fluid-property, and flow under ambient and pumped conditions. The geophysical logs were analyzed along with single-well aquifer test data and drilling logs to characterize the lithology, fabric, fractures, and flow zones penetrated by the wells. The results of the geophysical log analysis were used as part of the hydrogeologic characterization of the site and in the design of discrete-zone monitoring installations in the test wells and selected residential wells.

Most of the logged test and residential wells penetrated gneiss of the Hudson Highlands Complex or dolostones in the Wappinger Group, and some wells penetrated both the dolostone and gneiss. The bedrock fabric reflects the regional northeast-southwest structural trend, as well as localized folding, and includes foliation in the gneiss and bedding in the dolostone. Many fractures were oriented along the bedrock fabric, whereas others were orthogonal to the fabric.

Total wellbore transmissivity of the wells was estimated from short-term, single-well aquifer test data through the use of the Cooper-Jacob analytical solution. An empirical relation was established to estimate total wellbore transmissivity from specific-capacity data for wells with insufficient transient drawdown measurements. Wellbore transmissivity estimates ranged from 0.36 to 370 feet squared per day $\left(\mathrm{ft}^{2} / \mathrm{d}\right)$, whereas specific capacities ranged from 0.03 to 2.1 gallons per minute per foot $((\mathrm{gal} / \mathrm{min}) / \mathrm{ft})$.

Transmissivity and hydraulic heads of individual fracture zones were estimated from the total wellbore transmissivity and flow logs through use of an analytical model based on the Thiem equation. The model-estimated transmissivity of 95 fracture zones delineated in the 43 wells ranged from
0.25 to $340 \mathrm{ft}^{2} / \mathrm{d}$, with a median value of $6.7 \mathrm{ft}^{2} / \mathrm{d}$. The difference between model-estimated fracture-zone heads and the composite heads in each well ranged from less 0.01 to more than 10 feet (ft). Flow-log analysis generally provided an order of magnitude estimate for the fracture-zone hydraulichead difference on the basis of a comparison of estimated and measured values.

The geophysical logs and their analyses are available for display and download from the U.S. Geological Survey, New York Water Science Center, online geophysical log archive (http://ny.water.usgs.gov/maps/geologs/) in LAS (Log ASCII Standard), PDF, and WellCad formats.

\section{Introduction}

In 2001, the U.S Environmental Protection Agency (EPA) Region 2 requested the U.S. Geological Survey (USGS) to assist with the hydrogeologic assessment of the Shenandoah Road National Superfund Site in the Town of East Fishkill in Dutchess County, New York. This site is located on the ridge of Shenandoah Mountain, and past site activities have resulted in the contamination of more than 100 residential wells with volatile organic compounds, principally tetrachloroethene (PCE) and trichloroethane (TCE). As part of an initial effort, the USGS provided a background summary of both bedrock and surficial geology of the area (R.J. Reynolds, U.S. Geological Survey, written commun., 2001; on file at USGS Water Science Center, Troy, New York), well data, and ambient water-quality data. USGS staff reviewed workplans and reports prepared by consulting firms and provided technical commentary and suggestions, where appropriate.

Results of analysis of initial groundwater samples collected from April to August 2000 by the New York State Department of Health (NYSDOH) and EPA were used to identify 59 residential wells that were contaminated with PCE and other volatile organic compounds in concentrations greater than the Federal and New York State maximum contaminant levels (MCL) of $0.005 \mathrm{mg} / \mathrm{L}$. A total of 230 homes in the affected area were sampled at least once, and a pattern 
of contamination emerged from subsequent sampling events that revealed the highest levels of contamination [1,600 parts per billion (ppb) in a residential well] nearest the source, with overall levels of contamination decreasing with distance from the source. Subsequently, EPA installed point-of-entry-treatment (POET) systems in 105 of the affected homes.

Field work conducted by the New York State Department of Environmental Conservation (NYSDEC) and EPA on Shenandoah Mountain in October 2000 revealed the existence of a buried septic tank at a small industrial facility that contained extremely high levels of PCE. The facility on East Hook Cross Road, consisted of a small building that reportedly was used for the repair and cleaning of microchip racks used in computer chip manufacturing from the late 1960s through the mid-1970s. The septic system was filled with three layers of material: an upper liquid layer, a middle sludge layer, and a lower oily layer. All layers were contaminated with PCE; the lower oily layer was approximately 93 percent PCE $(934,000,000 \mathrm{ppb})$, whereas the middle layer had levels of up to 71,000,000 ppb PCE (U.S. Environmental Protection Agency, 2001). Although the chip-rack cleaning operation ceased in the mid-1970s, the septic system at this property had remained in limited use since then and provided a continuing source of groundwater contamination for approximately 30 years. On November 7, 2000, EPA removed ten 55 -gallon drums of liquid from the septic system to prevent further overflow into the soil. This septic system is believed to be the source of the groundwater contamination at the site (U.S. Environmental Protection Agency, 2001).

\section{Description of Study Area}

The study area is located in the Town of East Fishkill in southern Dutchess County, New York (fig. 1), and consists of residential subdivisions intermingled with extensive farmland and patches of woodlands. The homes in the area previously used private residential wells for potable water supply and septic systems for sanitary wastewater disposal. The study area is underlain by unconsolidated Pleistocene glacial deposits that overlie complexly folded, highly fractured and weathered dolostones that underlie the valleys, and up-thrusted fault blocks of the Precambrian gneissic basement rock that form the mountain ridges. The contamination site is located on the northeastern end of Shenandoah Mountain, which forms a ridge that is elongated in a northeast/southwest direction (fig. 1). The Precambrian gneiss that forms Shenandoah Mountain is overlain with a thin layer of glacial till. The adjacent valley to the east and north is underlain by dolostones and quartzite of the Cambrian/Ordovician-age Wappinger Group, which is in turn overlain by till, alluvium, and lacustrine sediments of variable thickness.

Most of the contaminated wells are located immediately adjacent to and topographically lower than the source site and continue into the valley in a predominantly northeast/ east direction. Groundwater is the sole source of water in the affected area. There are two aquifer types of concern in the area: a surficial aquifer of unconsolidated deposits and bedrock aquifers consisting of gneiss and dolostone. Results from residential well sampling conducted by NYDSOH and EPA from April through September 2000 indicate that these aquifers are interconnected. Residential wells on Shenandoah Mountain are completed in the gneiss, whereas wells in the valley are predominantly completed in the dolostone.

\section{Remedial Investigation of the Shenandoah Road National Superfund Site}

In November and early December 2000, EPA excavated the septic tank associated with the facility at 7 East Hook Cross Road and removed its contents for transportation and off-site treatment and disposal. EPA also excavated contaminated soil associated with the septic tank, which was temporarily stockpiled at the site. On the basis of results from field screening and analysis of post-excavation soil samples collected by EPA, it was evident that high levels of PCE still remained in the soil beneath the facility. As a result, it was necessary for EPA to demolish the facility prior to excavation of the underlying contaminated soil. During excavation of the contaminated soil associated with the former septic tank, two additional PCE disposal areas were discovered. Approximately 4,800 tons of contaminated soil associated with the former septic tank and the two PCE disposal areas were staged at the site and removed for off-site disposal by a potentially responsible party (PRP) in August 2001. Also, in August 2001, EPA discovered a buried "acid pit" behind the former 7 East Hook Cross Road facility. Field sampling results revealed high concentrations of PCE in the soil surrounding the acid pit, and EPA directed a PRP for the site to excavate the contaminated soil. Excavation activities associated with the former acid pit and off-site disposal of approximately 2,000 tons of contaminated soil were completed in January 2002.

In January 2001, EPA began an Expanded Site Inspection (ESI) in order to collect additional data and further delineate the extent of groundwater contamination. As part of the ESI, EPA's contractors conducted a limited bedrock investigation that included the installation of monitoring wells, borehole geophysics, and fracture trace analysis. EPA added the Shenandoah Road Groundwater Contamination Site in the town of East Fishkill, New York, (Dutchess County) to the Superfund National Priorities List on June 14, 2001 (U.S. Environmental Protection Agency, 2001).

In May 2001, EPA signed an Administrative Order on Consent (AOC) with International Business Machines (IBM). Under the AOC, IBM assumed responsibility for the completion of the soil removal action at the 7 East Hook Cross Road source area started by EPA, as well as continued maintenance of the POET systems in the affected homes. Also under the terms of the AOC, engineering consulting firms working for IBM evaluated alternate water-supply sources. IBM agreed to implement EPA's selected response action, including 


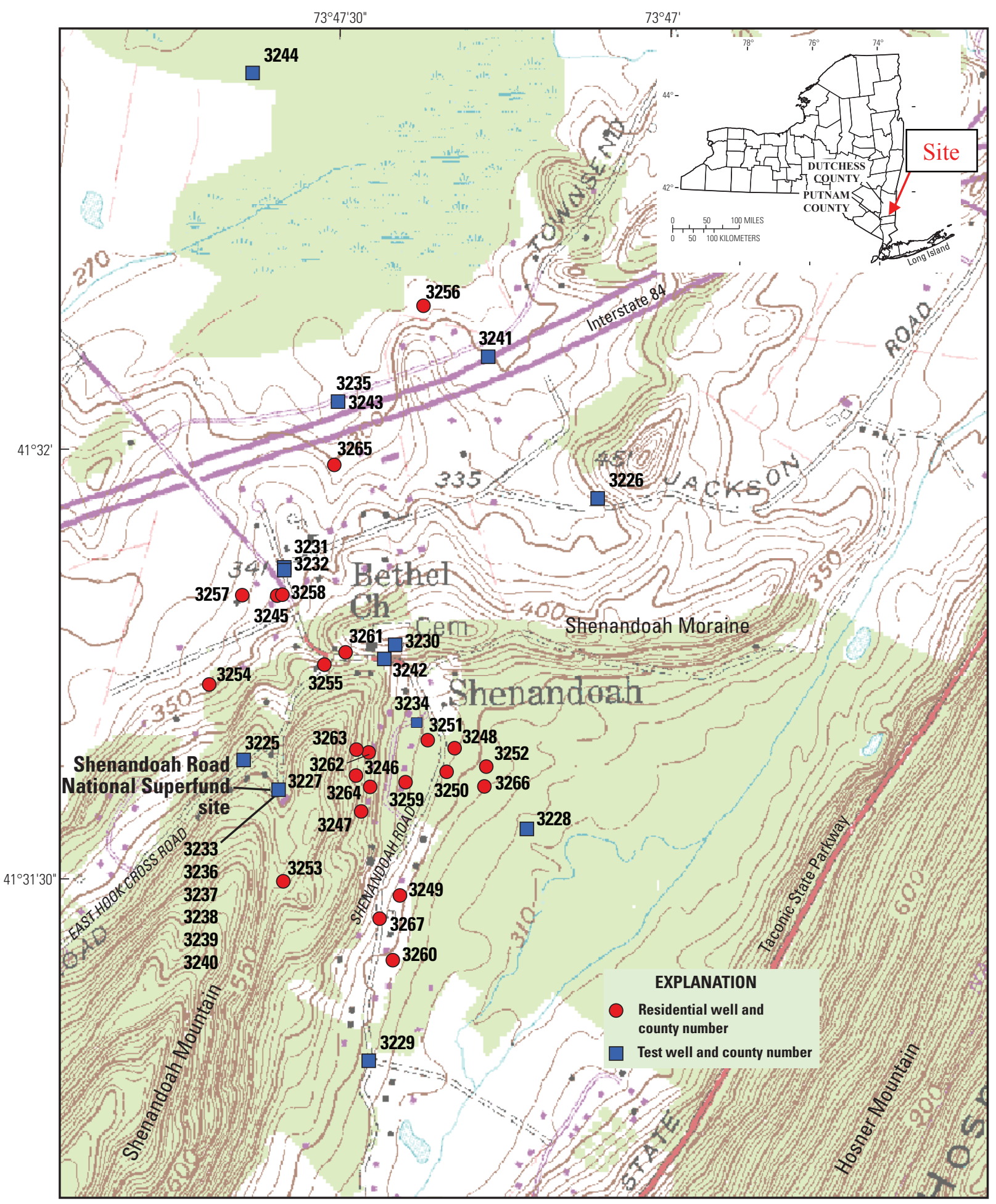

Base from U.S. Geological Survey, 1:24,000 series, Hopewell Junction, NY (1957)

Figure 1. Location of logged wells at the Shenandoah Road National Superfund Site, Dutchess County, N.Y. 
installation of the transmission piping and distribution system, and perform initial groundwater investigations in and around the site.

In August 2004, EPA issued a Decision Document, by which the Town of Fishkill Municipal Water Supply was selected as the permanent water supply for the affected residents at the site; the water supplier was chosen from the various previously identified water-supply alternatives. Under a second AOC with EPA, IBM has performed the Remedial Investigation/Feasibility Study (RI/FS). The Remedial Investigation involves gathering the groundwater, surface-water, and hydrogeologic data needed to determine the nature and extent of contamination at the site, whereas the Feasibility Study involves evaluating appropriate alternatives to remediate the contamination.

Several rounds of residential well sampling by the RI/FS contractor, Groundwater Sciences Corporation (GSC), have been conducted to document the extent of groundwater contamination from the source at this site. Water samples from 59 residential wells had concentrations that exceeded the MCL of $0.005 \mathrm{mg} / \mathrm{L}$ for PCE. Water samples from 20 wells had concentrations that exceeded the EPA Removal Action Level of $70 \mathrm{ppb}$ of PCE.

During 2006-07 and 2009-10, the USGS collected geophysical and flowmeter logs from drilled test holes to characterize the fractured-bedrock aquifer in the study area. The geophysical and flowmeter logs were analyzed along with drilling logs to define the stratigraphic units and flow zones intersected by the test wells. The location of the contributing flow zones within each wellbore was subsequently used by GSC to design discrete-zone monitoring installations for the test wells. The geophysical and flowmeter logging were critical to the RI/FS investigation in that they greatly aided the RI/FS contractor in their design of discrete-zone monitoring installations in both test and residential wells in a timely manner.

In 2008, construction of a pipeline to import publicly supplied water to the 120 affected homes began. Geophysical logs for 23 of the most contaminated residential wells were collected by the USGS during 2009-10 to identify fractures that were potential pathways for the movement of contaminated groundwater; these wells were subsequently converted to multi-zone monitoring wells by GSC because of the results of the geophysical logging and downhole volatile organic compound (VOC) sampling. Geophysical logs and flow logs from the 23 contaminated residential wells were collected under pumping and ambient conditions in order to identify the principal flow zones. Once the principal flow zones in each well were identified, a downhole, wireline, point water sampler was used to obtain water samples at each flow zone, under both ambient and pumped conditions. The location of the contributing flow zones in each well was subsequently used by GSC to design discrete-zone monitoring installations in selected residential wells.

\section{Purpose and Scope}

This report describes the geophysical logging methods used to evaluate and characterize 20 bedrock test holes and 23 residential wells at the Shenandoah Road National Superfund Site and presents the results of the analysis of the geophysical logs and aquifer tests used to characterize the lithology, fabric, fractures, and flow zones penetrated by each well. The report also gives estimates of the overall transmissivity of each borehole and presents a relation between borehole transmissivity and specific capacity.

\section{Bedrock Geology}

The Shenandoah Road National Superfund Site is situated atop Shenandoah Mountain, which is a northeast trending mountain that is part of the northern border of the Hudson Highlands (fig. 1). Shenandoah Mountain is primarily composed of Precambrian gneiss, whereas the surrounding lowlands are underlain by carbonate units of the Wappinger Group. These rock units are described in more detail below.

\section{Precambrian Gneiss}

The greater part of Shenandoah Mountain is composed of Precambrian (Proterozoic-age) garnet-bearing gneiss with interlayered quartzite of the Hudson Highlands Complex gneisses. Mineralogically, the gneiss contains biotite, garnet, sillimanite, minor marble, amphibolite, and rusty para-gneiss. Helenek (1972) refers to this rock as "biotite migmatic gneiss, garnetiferous facies." Shenandoah Mountain is one of a series of enechelon, fault-bounded structural blocks that compose the northern edge of the Hudson Highlands in southern Dutchess County. These blocks are composed of gneissic rock that has resulted from intense plastic deformation and at least one episode of brittle deformation (tectonics). Evidence of brittle deformation is widespread in the study area. Helenek (1972) reported that minor faults and microfractures in the gneiss are abundant; most faults appear to be strike-slip faults with left-lateral strike-slips predominating. Three directions of strike-slip movement are prominent- N. $10^{\circ} \mathrm{W}$., N. $52^{\circ} \mathrm{W}$., and $\mathrm{N} .27^{\circ} \mathrm{E}$. - with most fault planes inclined at a high angle (about $60^{\circ}$ ) to the south (Helenek, 1972). Two prominent joint sets are also found in the gneiss, a dominant set trending N. $39^{\circ} \mathrm{W}$. with a dip of $80^{\circ} \mathrm{S}$ and a second set trending N. $75^{\circ} \mathrm{W}$. and dipping $85^{\circ} \mathrm{N}$.

\section{Wappinger Group}

Carbonate units, primarily the Wappinger Group, that overlie and abut the gneisses of the Hudson Highlands Complex are Paleozoic (Cambrian and early Ordovician) rocks (Fisher, 1977). The Wappinger Group, as described by 
Fisher (1977) consists of a series of Cambrian and Ordovician carbonate units, beginning with the Poughquag Quartzite (of Dana, 1872) at the base and ending with the Copake Limestone (of Dana, 1872) at the top. Other stratigraphers, such as Dana (1879), include the overlying Balmville Limestone (of Holzwasser, 1926); however, more recent correlation charts (Fisher, 1977) omit the Balmville Limestone. The Wappinger Group, as mapped and defined by Fisher (1977) consists of the following units (from oldest to youngest): Poughquag Quartzite (of Dana, 1872), Stissing Dolomite (Ratcliffe and Burton, 1990), Pine Plains Formation (of Knopf, 1946), Briarcliff Dolomite (Ratcliffe and Burton, 1990), Halcyon Lake Formation (Ratcliffe and Burton, 1990), Rochdale Formation (of Dwight, 1887), and the Copake Limestone (of Dana, 1879). Helenek (1972) describes only the three lowermost carbonate units of the Wappinger Group, which he calls units A, B, and C. Unit A is roughly equivalent to the Stissing Dolomite, unit $\mathrm{B}$ is the equivalent of the Pine Plains Formation, and unit $\mathrm{C}$ is equivalent to the Briarcliff Dolomite. Within the immediate Shenandoah Road Superfund Site study area, only the Stissing Dolomite, Pine Plains Formation, and Briarcliff Dolomite are thought to be present (Offield, 1962; Fisher, 1968; Helenek, 1972). These units are briefly described in ascending stratigraphic order below.

\section{Poughquag Quartzite}

The Poughquag Quartzite is the lowest unit of the Wappinger Group and is separated from the underlying Precambrian gneisses by a folded angular unconformity. Helenek (1972) reported that the Poughquag Quartzite is always separated from the underlying gneisses by a 3-ft-thick zone of massive arkose metaconglomerate. The metaconglomerate is a drab olive-gray to dull yellowish-white, poorly sorted, massive to slightly gneissoid rock with a variable grain size. Helenek (1972) regarded this metaconglomerate as a transitional horizon between the Poughquag Quartzite and the underlying gneisses because the pronounced foliation in the gneisses gradually disappears in the basal part of the metaconglomerate. The upper part of the metaconglomerate exhibits faint bedding parallel to that of the quartzite. The contact between the metaconglomerate and the Poughquag Quartzite is sharp, and the basal part of the quartzite consists of interlensed quartzite, subarkose, and quartz conglomerate. The quartzitic facies is a massive to well-layered, white, buff, rusty brown or gray, well-sorted, fine-grained quartz sandstone. The conglomeratic facies contains pebbles of angular to subangular quartz and microcline set in a quartzite matrix. The Poughquag Quartzite is the equivalent of the Cheshire Quartzite of western Massachusetts and is a compact, competent rock so tough to drill that it is deliberately avoided by water-well drillers (Simmons and others, 1961).

\section{Stissing Dolomite}

The Stissing Dolomite is a massive, white to light-gray, fine grained, foliated dolostone that weathers to a pale gray where exposed in outcrops. The contact between the Stissing Dolomite and the underlying Poughquag Quartzite is gradational, with interlayering of quartzite and quartz-bearing dolostones over a stratigraphic distance of up to $50 \mathrm{ft}$ (Fisher and McLelland, 1975). Gray or green shale interbeds are present in some intervals, as are localized chert, quartzite layers, and quartz-filled fractures. In some sections, dark, laminated dolomite layers are observed. The total thickness of the Stissing Dolomite is estimated to be about $500 \mathrm{ft}$ (Knopf, 1946), which matches the thickness estimate of Fisher and Warthin (1976) in western Dutchess County. The lower and middle sections of the Stissing Dolomite have been interpreted to be of Lower Cambrian age, whereas the uppermost section may be Middle Cambrian in age.

\section{Pine Plains Formation}

The Pine Plains Formation of Middle to Upper Cambrian age is the most highly variable unit within the Wappinger group; it has the varying colors and textures of dolostone that alternate with sandstone or quartzitic dolostone beds. Bedding tends to be graded and cyclical with variable bedding thicknesses and with the dolostone commonly alternating with dark gray shale interbeds. Oolites, ripple marks, cross-laminations, and desiccation cracks are common. The thickness of the Pine Plains Formation has been estimated to be 90 to $1,300 \mathrm{ft}$ (Helenek and Mose, 1976; Knopf, 1946); however, in western Dutchess County its thickness has been estimated to be 1,150 ft (Fisher and Warthin, 1976).

\section{Briarcliff Dolomite}

The Briarcliff Dolomite of Upper Cambrian age consists of massively bedded, light-to-dark gray, arenaceous, quartzitic dolostones that weather to colors ranging from tan to orangebrown to brown. Thickness estimates for the Briarcliff Dolomite range from 215 to 1,000 ft (Helenek and Mose, 1976; Knopf, 1946).

\section{Structural Geology}

The gneissic rocks of the Precambrian Hudson Highlands Complex in southern Dutchess County have been deformed into a series of open to closed, asymmetrical and overturned folds that gently plunge to the northeast. All of these are flexural slip folds with movement occurring along bedding and foliation planes (Helenek, 1972). The limestone and dolomite units of the Wappinger Group have been metamorphosed to various degrees; the intensity of the metamorphism increases from northwest to southeast across Dutchess County. In the 
southeastern part of the county, the marble units there have been so severely deformed by plastic flow that they appear to be wrapped around more competent rock units (Simmons and others, 1961). Shenandoah Mountain itself is bounded by a normal fault to the east in which the adjacent valley (underlain by the Wappinger Group) represents the downthrown side. Another normal fault similarly defines the east side of Round Mountain (East Hook), just west of Shenandoah Mountain. Fisher (1968) mapped a third normal fault between those two, running northeast through the Wappinger Group, with the downthrown side to the west. Very few actual measurements of strike and dip of bedding or jointing have been made by field investigators on Shenandoah Mountain. Offield (1962) made three strike and dip measurements (presumably of jointing) in the Precambrian gneisses of Shenandoah Mountain along the Dutchess-Putnam county line. His values were (approximately) N. $38^{\circ}$ E., with a dip of $70^{\circ} \mathrm{SE} ; \mathrm{N}$. $35^{\circ} \mathrm{E}$., with a dip of $20^{\circ} \mathrm{NW}$; and N. $27^{\circ} \mathrm{E}$., with a dip of $70^{\circ}$ SE. Offield (1962) also made a measurement within the downthrown block of amphibolite, just east of the eastern Shenandoah Mountain fault, which was (approximately) N. $16^{\circ}$ E., with a dip of $52^{\circ}$ SE. These limited data appear to show the predominant high-angle joint set on Shenandoah Mountain to trend about N. $30^{\circ}$ to $35^{\circ}$ E. and dip steeply $\left(70^{\circ}\right)$ to the southeast. This pattern is repeated to the west of the study area, near Sharp Reservation, where many strike and dip measurements made by Helenek (1972) in the Precambrian gneisses reveal a similar trend.

Little data are available on the strike and plunge of folding on Shenandoah Mountain. Helenek (1972) noted that in the vicinity of Sharp Reservation, to the west, the axial planes of folds in the Precambrian gneisses trend about N. $46^{\circ}$ E. and $\operatorname{dip} 80^{\circ} \mathrm{N}$., and the fold axes strike N. $45^{\circ}$ E. and plunge $12^{\circ}$ $\mathrm{N}$. However, regional tectonics has caused the axial planes of folds in the overlying Wappinger Group to be rotated to the north. Helenek (1972) noted that, southeast of Wiccopee, folds in the dolostones within the Wappinger Group have axial planes oriented about N. $7^{\circ} \mathrm{E}$. with a dip of $58^{\circ} \mathrm{S}$. and with the fold axes rotated and trending N. $25^{\circ}$ E. and plunging $14^{\circ} \mathrm{N}$. Slaty cleavage and foliation in the Wappinger Group is parallel or subparallel to the axial planes of folds. Helenek (1972) also noted that faults in the Paleozoic gneisses are either high-angle normal faults or low-angle thrust faults; some thrust faults are at an almost horizontal plane. Brecciated fault planes were usually cemented with coarse-grained quartz and carbonate minerals.

\section{Surficial Geology}

Deglaciation in the vicinity of Shenandoah Mountain left a variety of surficial deposits and landforms, including end moraines, ice-contact deposits of sand and gravel, valley train outwash, fine-grained lacustrine deposits, and till. The surfical geology in the area was mapped on a materials basis by
Gerber (1982) and on a morphostratigraphic basis by Connally (1980). Reynolds and Calef (2010) summarize the surficial geology of the Sprout and Fishkill Creek drainages just to the north of Shenandoah Mountain.

Connally and Sirkin (1986) detail the chronology of the deglaciation of the mid-Hudson valley in Dutchess and Columbia Counties and define a series of ice-marginal positions along with the associated morainal landforms. In general, the valleys of Sprout Creek, Wiccopee Creek, and Whortlekill Creek are all floored with valley train outwash, which is underlain by thick deposits of lacustrine silt and clay (Reynolds and Calef, 2010). The Precambrian bedrock uplands (Shenandoah, Hosner, and Honess Mountains) are covered with a thin (less than $6 \mathrm{ft}$ thick) veneer of till; however, the steepest slopes are generally exposed bedrock. In the vicinity of East Fishkill, exposed outcrops of Wappinger Group rocks are covered with a thin veneer of till, and in the main valleys near Hopewell Junction, north-south trending drumlinoid hills punctuate the pitted outwash of the Sprout Creek valley (Reynolds and Calef, 2010).

\section{Shenandoah Moraine}

The most notable glacial landform that may affect the hydrogeology of the Shenandoah Road Superfund site is the Shenandoah Moraine (Connally and Sirkin, 1986; Reynolds and Calef, 2010, sheet 2), a discontinuous string of ice-contact deposits that mark an ice-marginal position that stretches for about 3 miles from just south of Beacon, N.Y., along the northern edge of the gneisses of the Hudson Highlands Complex (Honess, Shenandoah, and Hosner Mountains) to the village of Poughquag near West Mountain. Connally and Sirkin (1986) tentatively correlated the Shenandoah Moraine with the Pellets Island Moraine in the Wallkill River valley to the west and estimated the age to be about 17,500 years before present.

The Shenandoah Moraine, although it may mark an icemarginal position, appears to be mostly composed of ice-contact, stratified drift (a kame moraine) instead of till. Gordon (1911) recognized the 180-ft high landforms that "guard the approach to Shenandoah hollow" as kames, and Connally and Sirkin (1986) state that the moraine is mostly composed of fragmentary landforms of stratified drift. Gerber (1982) simply labels it as sand and gravel, and Connally (1980) maps it as kame sand and gravel. The part of the moraine that blocks the entrance to the narrow valley between Shenandoah and Hosner Mountains appears from the topography to be composed, either wholly or in part, of either eskers or ice-channel fillings. The narrow ridge that begins at the nose of Shenandoah Mountain and extends east-west across the narrow valley appears to be an esker, and other parts of this segment of the moraine appear to display ice-contact slopes. Another segment of this kame moraine to the northeast across the Taconic State Parkway contains a gravel pit and shows evidence of being an ice-channel filling. Two wells, a dug well (Du-961) and a driven well (Du-444) (Reynolds and Calef, 2010, sheet 
1) tap these deposits to depths of about $25 \mathrm{ft}$. At least one of these wells (Du-961) has had a sufficient yield to supply water to 60 head of livestock (Simmons and others, 1961). These ice-contact deposits of sand and gravel are deposited atop Wappinger Group carbonates and may represent areas where recharge to the underlying bedrock aquifer is facilitated.

\section{Outwash Sand and Gravel}

Outwash sand and gravel compose the floors of the valleys of Sprout and Wiccopee Creeks, extending southward from Fishkill Plains to the IBM facility at East Fishkill (Reynolds and Calef, 2010, sheet 2). Much of this outwash is what is known as pitted outwash, which is outwash punctuated by numerous small closed depressions that indicate deposition around small blocks of disintegrating glacial ice. Beneath the outwash are deposits of lacustrine silt and clay deposited into Glacial Lake Fishkill (Connally and Sirkin, 1986), which occupied the Sprout and Whortlekill Creek valleys as the ice receded northward from the Shenandoah Moraine to an ice-margin near Poughkeepsie, N.Y. Logs of wells in the Wiccopee Creek valley, about 3 miles northwest of the Shenandoah Road National Superfund Site, show that the surficial outwash is thin in most areas and absent in others but that a lower confined sand and gravel aquifer is present in some places. For example, well Du-429 at Wiccopee was drilled to $116 \mathrm{ft}$, penetrating $63 \mathrm{ft}$ of gray silt before passing through $30 \mathrm{ft}$ of fine sand and gravel and entering brown clay. The driller noted that the $30 \mathrm{ft}$ of sand and gravel was the main water-bearing zone. Heads in this confined sand and gravel aquifer are, at least seasonally, above land surface. Nearby well Du-476 at Wiccopee is $85 \mathrm{ft}$ deep, flowed at 3 gallons per minute (gals/min) when originally drilled, and appears to be completed in the same confined aquifer as well Du-429. Well $\mathrm{Du}-465$ is closer to the Shenandoah Road site than the other two wells, is $230 \mathrm{ft}$ deep, yields $18 \mathrm{gals} / \mathrm{min}$, and is completed in ice-contact sand and gravel that abuts the northwest side of Shenandoah Mountain.

\section{Description of Wells}

Twenty test wells and 23 residential wells were logged by downhole geophysical methods at the Shenandoah Road National Superfund Site. The locations of the logged wells are presented in figure 1. Well location and construction information and the ambient water level recorded at the time of geophysical logging are presented in table 1 .

\section{Test Wells}

Of the 20 test wells (Du-3225 to Du-3244) constructed under the direction of GSC, 19 are 6-inch (in.) diameter openhole wells, and one, well Du-3227, is a 4-in. diameter core hole. All wells were drilled by a commercial well driller using an air-hammer drill rig. Most of the test wells were designed to have depths of $500 \mathrm{ft}$; however, some were completed at lesser depths. The casings were installed into the top of bedrock in all of the test wells, except Du-3233, Du-3236, Du-3237, and Du-3240, which are near the contamination source and have casings set to targeted depth intervals, and wells Du-3232 and Du-3244, which are cased to $155 \mathrm{ft}$ and $269 \mathrm{ft}$, respectively. Each test well was completed by GSC with a Flute liner that has multiple water-quality and hydraulic-head measurement ports installed at the depth of flow zones identified through the geophysical $\log$ analysis.

\section{Residential Wells}

The 23 residential wells were constructed as 6-in-diameter open-hole wells with casings that terminate just below the top of bedrock, except for Du-3257, which was finished as a shallow sand and gravel well. The residential wells selected for logging were known to produce water with PCE concentrations greater than drinking-water standards and were no longer in use following the installation of the public-watersupply system. Prior to USGS logging, GSC arranged to have the submersible pumps pulled and subsequently inspected each well with a downhole camera to insure that there were no obstacles in the wellbore. GSC personnel also interviewed each homeowner, explained the nature of the geophysical logging, and obtained signed well-access agreements before the USGS could proceed with the logging. The wells were logged in three phases; 7 wells were logged during August and September 2009, 13 wells during October 2009, and 3 wells during January 2010. Selected residential wells were completed by GSC with 2-inch (in.) diameter casings and screens to isolate flow zones identified through the geophysical-log analysis for subsequent water-quality sampling and hydraulichead measurement.

\section{Data Collection}

Geophysical logs and associated data were collected from the 20 test wells and 23 residential wells at the Shenandoah Road National Superfund Site. The types of logs collected from each well are shown in table 2. Drilling logs for the test wells were collected by GSC and provided to the USGS.

\section{Drilling Logs for Test Wells}

Drilling logs are records of observations from the drilling operation and include lithology of drill-cuttings, blown-yield, and fracture logs. The three types of drilling logs collected at the site are described below.

Drill-cuttings logs are records of the lithology of unconsolidated sediments and bedrock types penetrated by the well 


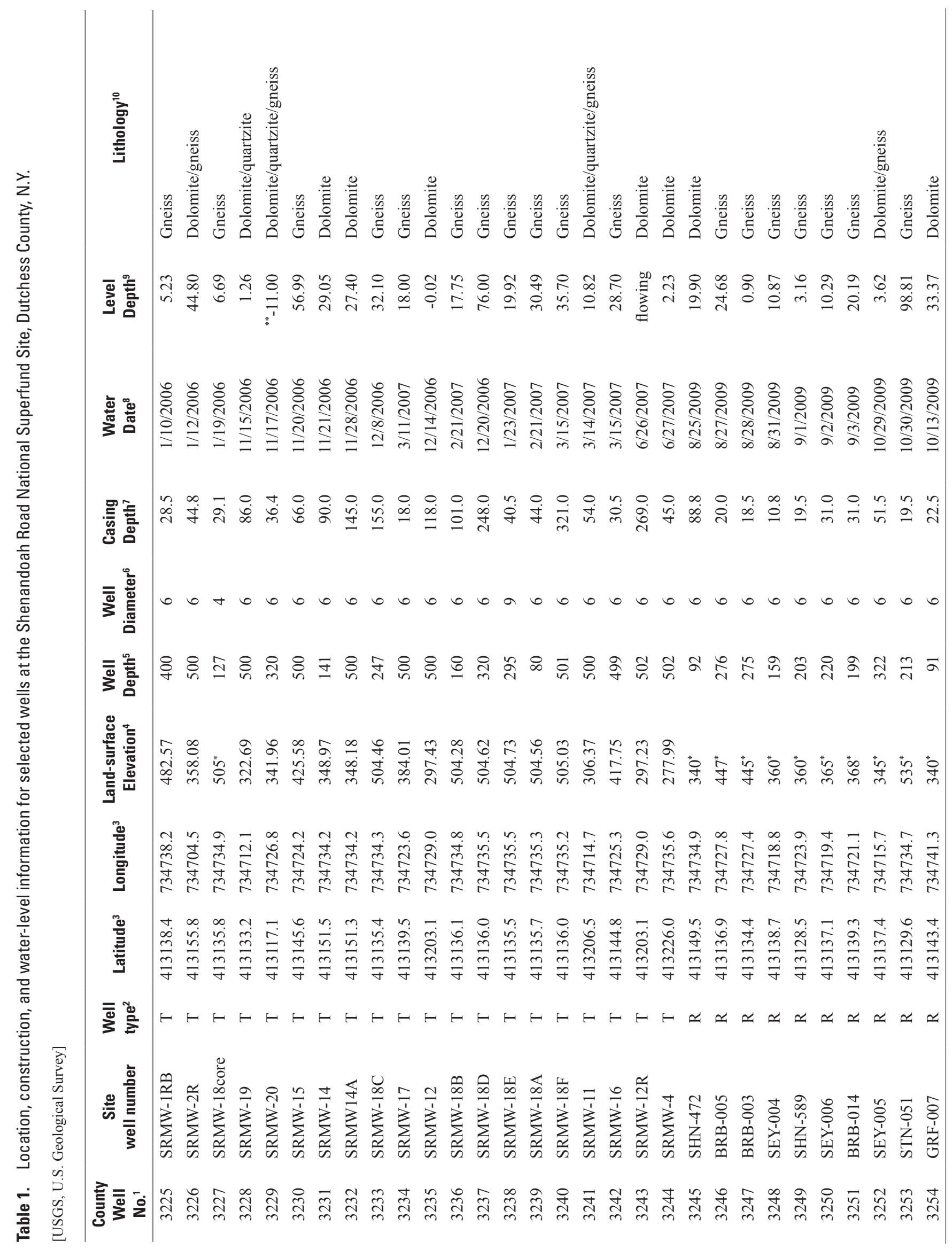




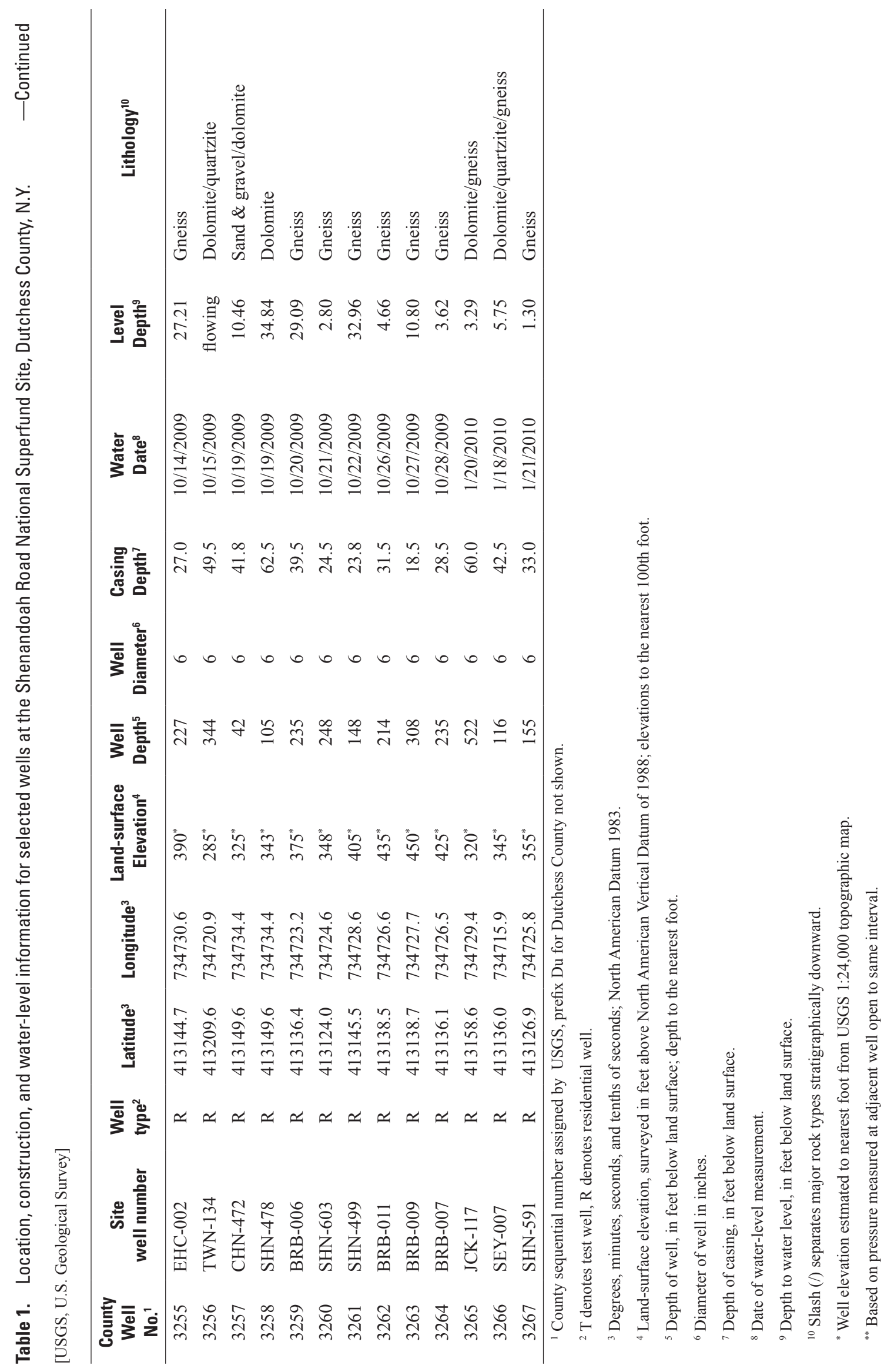




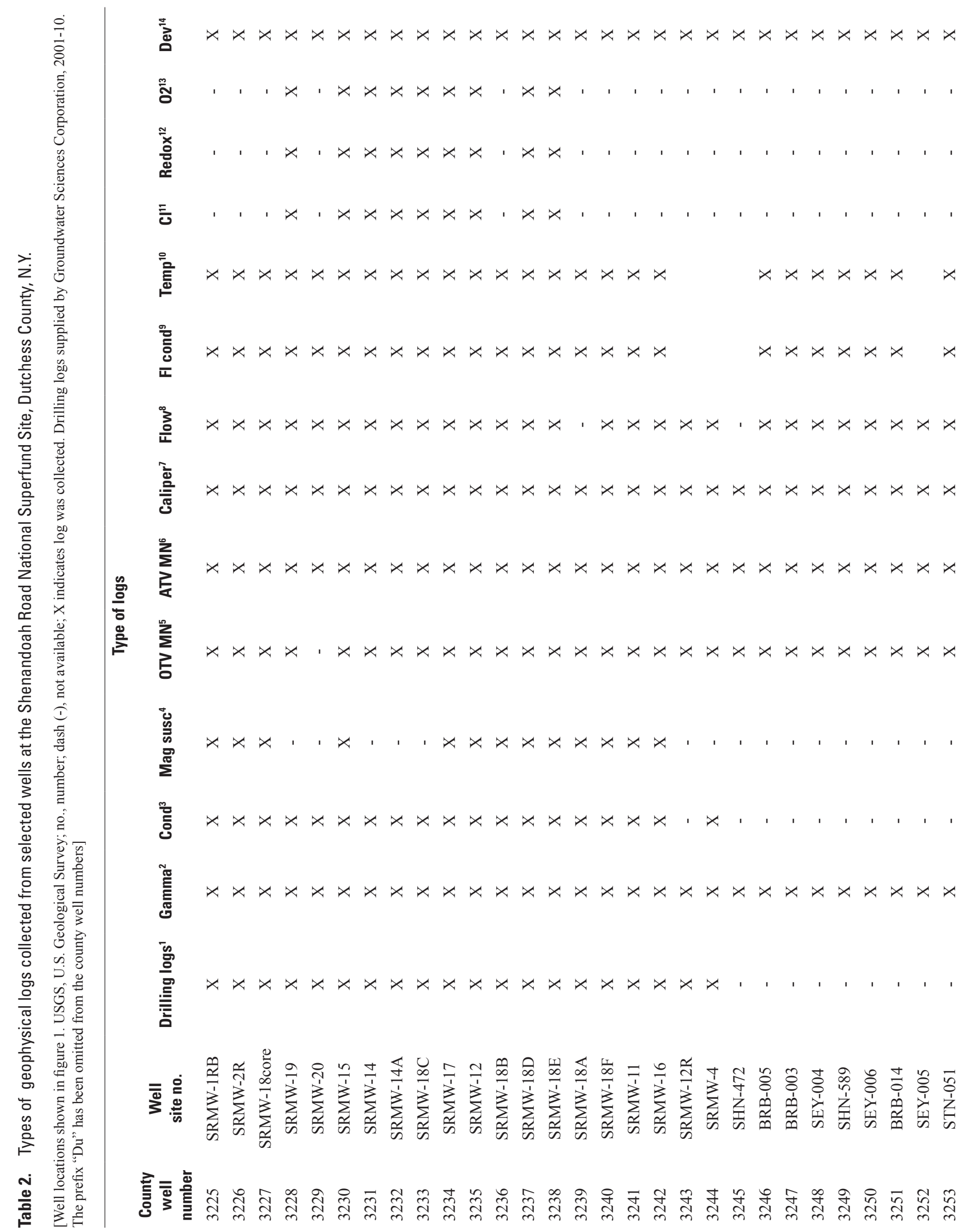




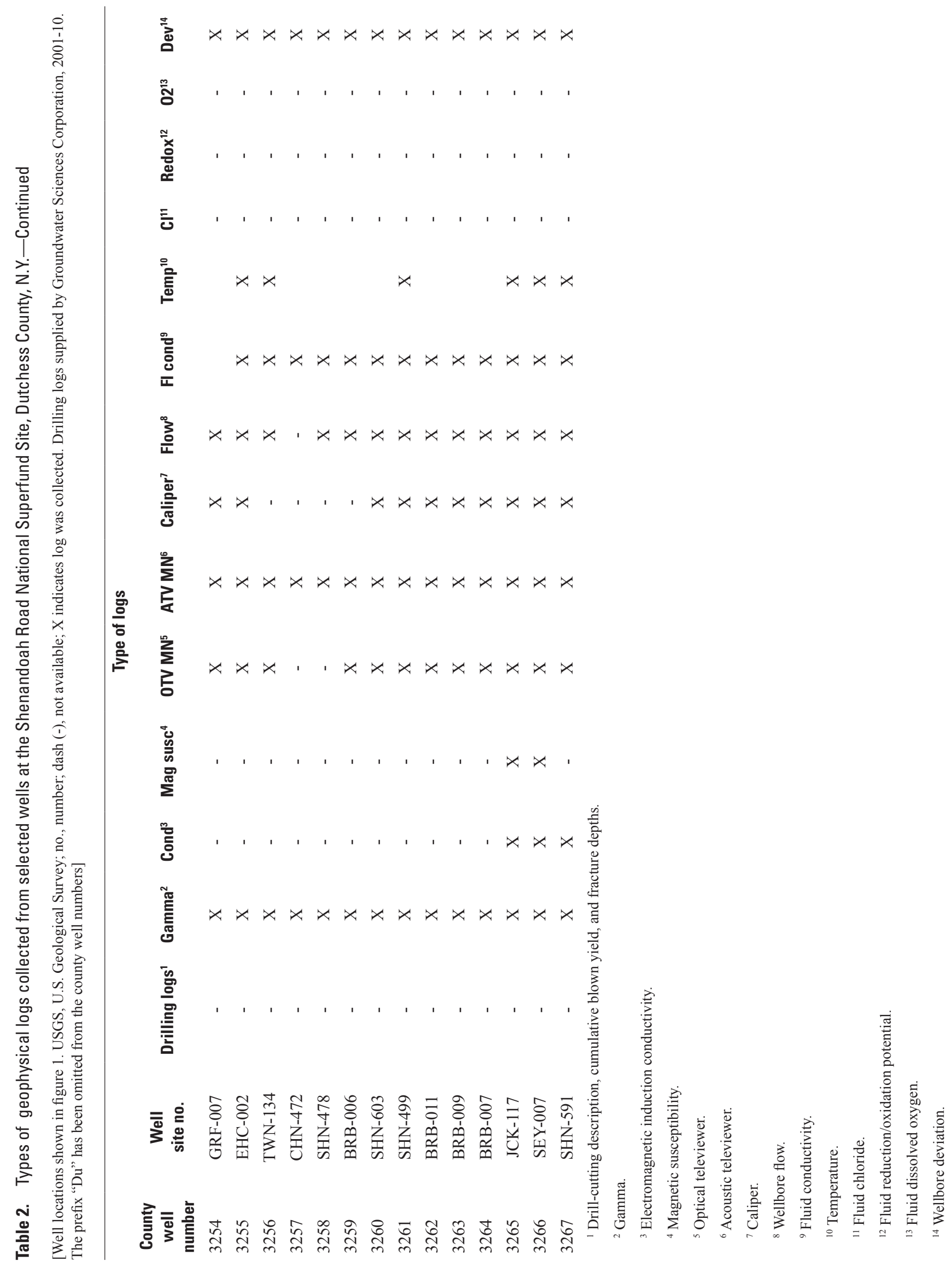


and are based on the GSC geologist's description of samples of drill cuttings collected at selected depth intervals. Continuous-core samples were collected at Du-3227 and described by the GSC geologist.

Blown-yield logs are records of the cumulative discharge blown from the well during air-hammer drilling. They provide an estimate of the cumulative water yield of the wellbore while drilling.

Fracture logs are records of fractured zones detected during drilling. Penetration of fractured zones during drilling may be indicated by increased drilling rates, sudden drops in drill bit position, and loss or gain of drilling fluids.

\section{Geophysical Logs}

Geophysical logs were collected by the USGS using a truck-mounted drawworks that holds approximately $2,000 \mathrm{ft}$ of armored four-conductor cable. Each downhole tool (probe) is attached to the cable head and run down the well at the prescribed speed for each geophysical tool. Most tools collect data on multiple characteristics; for example, the fluid-conductivity probe collects fluid conductivity, temperature, and gamma logs simultaneously. Data-collection speeds (rates of descent or ascent) range from 20 feet per minute (ft/min) for most logging tools to about $5 \mathrm{ft} / \mathrm{min}$ for the optical and acoustic logging tools. Data from each tool are continually recorded on a laptop computer and are viewed in real time in the field.

Examples of the types of geophysical logs collected from both the test holes and the residential wells are presented in appendix 1 and include gamma, caliper, borehole-image, deviation, fluid-property, electromagnetic-induction, magneticsusceptibility, and flowmeter logs. The caliper logs were collected by mechanical and acoustic methods. Boreholeimage logs were collected with an optical televiewer (OTV) and an acoustic televiewer (ATV). Borehole-deviation logs were collected with three-axis fluxgate magnetometers and vertical inclinometers that are incorporated into the ATV and OTV probes. Fluid-property logs included fluid-conductivity, temperature, dissolved oxygen, chloride, and redox potential measurements of the borehole water. Flowmeter logs were collected by heat-pulse or electromagnetic methods. The types of geophysical logs collected in each well are listed in table 2.

Applications of geophysical logs in groundwater studies are described by Williams and Lane (1998) and Keys (1990). The geophysical logs used in this investigation are described briefly below.

Gamma logs measure the natural gamma radiation of the rock units penetrated by the borehole. Major gamma emitters are uranium, thorium, and daughter products of potassium- 40 . Sedimentary rocks with relatively high gamma radiation when compared to other lithologic units include shales, mudstones, and other argillaceous units. Igneous and metamorphic rocks rich in potassium feldspar are also high gamma emitters. The gamma tool has a vertical resolution of 1 to $2 \mathrm{ft}$. Gamma logs collected in open holes and through steel casing may be used for lithologic identification and stratigraphic correlation.

Electromagnetic-induction conductivity logs measure the electrical conductivity of bedrock and water surrounding the borehole. In this study, the logs were collected at a frequency of 40 kilohertz $(\mathrm{kHz})$. The electromagnetic-induction tool has a vertical resolution of about $2 \mathrm{ft}$ and primarily samples volumes to about $18 \mathrm{in}$. radially from the well. It generally is not affected by the electrical properties of the wellbore fluid for diameters less than 8 in. Electrical conductivity measurements are affected by the argillaceous content and porosity of the rocks and by the concentration of dissolved solids in the pore fluid. Electromagnetic-induction conductivity logs are most effective in formations with high electrical conductivities (low resistivities), such as shales and mudstones.

Magnetic-susceptibility (MAG) logs provide a record of the variations in magnetic minerals within the surrounding rock. Magnetite is the most common magnetic mineral, and local variations in its abundance may indicate lithologic contacts.

Mechanical and acoustic caliper logs record the diameter of the borehole. Changes in borehole diameter are related to drilling and construction procedures and competency of lithologic units, fractures, and solution features. Mechanical-caliper logs were collected with a spring-loaded, three-arm averaging tool; acoustic-caliper logs were calculated from acoustic travel times collected with the ATV tool. Caliper logs were used in the delineation of fractures, solution features, and lithology, and to confirm well and casing depths and diameters.

ATV logs record a 360-degree magnetically oriented acoustic image of the borehole wall (Williams and Johnson, 2000). ATV logs can be collected in clear or turbid water. The ATV provides high-resolution information on the location and strike and dip of fractures or bedding within a borehole, such that structural features with widths greater than $0.02 \mathrm{ft}$ can easily be identified. ATV logs were used to characterize bedding and lithology, fracture aperture and orientation, solution features, and borehole-wall roughness.

OTV logs record a 360-degree oriented optical image of the wellbore wall. OTV logs can be collected above the water level and below the water level where the water is clear. Features with widths greater than $0.008 \mathrm{ft}$ can be identified. OTV logs were used to characterize bedding and lithology, fractures, and solution features (Williams and Johnson, 2000).

Deviation $\operatorname{logs}$ measure the inclination and direction of the well from vertical. Inclination generally is measured within \pm 0.5 degree and direction within \pm 2 degrees. Deviation direction is given in magnetic north. In test wells that penetrate magnetite bearing zones, deviation direction can be affected by the secondary magnetic field generated by the ferrous minerals.

Temperature (Temp) logs record the temperature of air and water in the wellbore. Temperature gradients that deviate from the geothermal gradient may indicate intervals of wellbore flow. Temperature logs were used to delineate the water level and possible changes in wellbore flow. 
Fluid-conductivity (Cond) logs record the electrical conductance of water in the wellbore. Electrical conductance is directly related to the concentration of dissolved solids in the water. Slope changes in fluid-conductivity logs may indicate zones of inflow to, or outflow from, the borehole. Fluidconductivity logs were used to delineate possible changes in wellbore flow.

Fluid dissolved oxygen logs record the amount of dissolved oxygen, in parts per million, of water in the wellbore. Slope changes in dissolved oxygen logs may indicate zones of inflow to, or outflow from, the wellbore. Dissolved oxygen logs were used to delineate possible changes in the wellbore flow.

Fluid chloride logs record the amount of chloride, in milligrams per liter, of water in the wellbore. Slope changes in chloride logs may indicate zones of inflow to, or outflow from, the wellbore. Chloride logs were used to delineate possible changes in the wellbore flow.

Fluid redox logs record the oxidization or reduction potential of the water in millivolts. Slope changes in redox logs may indicate zones of inflow to, or outflow from, the wellbore. Redox logs were used to delineate possible changes in the wellbore flow.

Flow logs record the direction and rate of vertical flow in the borehole. Vertical flow occurs in wells that penetrate two or more water-producing fracture zones with different hydraulic heads (water levels). Flow in the borehole is from zones of higher head to zones of lower head. The heat-pulse flow meter (Hess, 1982) measures the travel time of a thermal pulse between a set of upper and lower heat sensors (thermistors). The flowmeter was used with flexible rubber diverters fitted to the nominal borehole diameter and has a measurement range of 0.01 to 1.5 gallons per minute $(\mathrm{gal} / \mathrm{min})$ in a stationary mode. Flow logs and fluid-property logs were collected (when possible) under (1) steady-ambient ( $\mathrm{amb}$ ) conditions and (2) steady-pumping (pmp) or transient-recovery (rec) conditions to provide a contrast of flow-rate gain or loss at discrete fracture zones with the boreholes (Paillet, 2000; 2001). To measure higher borehole flows, an electromagnetic flowmeter was used. The electromagnetic flowmeter (Young and Peterson, 1995) measures fluid velocity, based on Faraday's Law, which states that the flow of an electrically conductive fluid through an induced magnetic field generates a voltage gradient that is proportional to its velocity. The electromagnetic flowmeter, which was used in stationary and trolling modes with a flexible rubber diverter fitted to the borehole diameter, has a measurement range of 0.05 to $15 \mathrm{gal} / \mathrm{min}$.

\section{Single-Well Aquifer Tests}

To estimate the total wellbore transmissivity of each well, short-term, single-well aquifer tests were conducted in conjunction with pumped flow logging operations. A small submersible pump was set in the well near the top of the water column and pumped at a low flow rate, generally about $1 \mathrm{gal} /$ min. In most wells, drawdown in the well was measured continuously with a pressure transducer verified by regular check measurements with a water-level tape. After quasi-steady-state drawdown was achieved, downhole flowmeter measurements were made at multiple depths within the well. The transient drawdown data were plotted against time, and the CooperJacob method (Cooper and Jacob, 1946) was used to estimate transmissivity for the open part of the wellbore. Assumptions of the method include that the aquifer is confined and has infinite areal extent, the aquifer is homogenous and isotropic, flow is horizontal to the well, and water is released from storage instantaneously. For the purposes of estimating transmissivity in these wells and comparisons with other estimates, these assumptions were considered appropriate.

\section{Geophysical Log Analysis}

The geophysical logs and associated data were analyzed to characterize the lithology, structural features (fabric and fractures), and flow zones penetrated by the wells. The geophysical logs along with the results of short-term, singlewell aquifer tests were used to estimate the transmissivity of individual flow zones and the overall transmissivity of the wellbore.

\section{Lithology}

The suite of geophysical logs, primarily the optical televiewer and gamma logs, were used in conjunction with the drill-cuttings logs to identify the different rock types that were penetrated by the wells. These rock types were then correlated with mapped rock units in the study area as defined by Fisher and others (1970). Drill-cutting logs were not available for the 23 residential wells that were logged, so identification of the bedrock lithology was based on the suite of geophysical logs collected in each well and their relation to the lithology established in the test wells. Tentative identification of rock types in each well were made with the aid of the OTV, ATV, electromagnetic-induction, magneticsusceptibility, and gamma logs; identification was confirmed by comparison to the extent of mapped bedrock units in the study area, as defined by Fisher and others (1970), and field mapping conducted by Offield (1962), Fisher (1968), and Helenek (1972). There are three types of rock that the test wells penetrate-gneisses of the Hudson Highlands Complex that compose the Shenandoah Mountain ridge, and dolostones and quartzites of the Wappinger Group that underlie the valley (table 1). The test wells that penetrate the Hudson Highland Complex gneisses are Du-3225, Du-3227, Du-3230, Du-3233, Du-3234, Du-3236, Du-3237, Du-3238, Du-3239, Du-3240, and Du-3242. The wells that penetrate the Wappinger Group dolostones and quartzite are Du-3226, Du-3228, Du-3229, Du-3231, Du-3232, and Du-3235. Wells Du-3226, Du-3229, and Du-3241 penetrate the Wappinger Group dolostones and 
quartzite and continue into the Hudson Highland Complex gneisses.

The gamma logs in the Hudson Highland Complex gneisses average 250 to 300 counts per second, although there are large variations with values ranging from less than 70 to more than 800 counts per second. The gamma values vary with pegmatite content within the gneiss; the more pegmatite present, the higher the gamma count as a result of the larger percentage of potassium feldspar in the pegmatite. The quartzite and dolostone gamma values are generally lower, averaging 100 to 150 counts per second but may range from 10 to 280 counts per second, depending on the shale content. The electromagnetic-induction logs average 10 to 20 millisiemens per meter $(\mathrm{mS} / \mathrm{m})$ in all three rock units with variations as low as 1 and as high as $50 \mathrm{mS} / \mathrm{m}$.

In the gneiss, higher values of electromagnetic induction generally correspond with zones of higher magnetic susceptibility. The dolostone variations in the electromagnetic-induction log correspond with the gamma log, which shows higher values with greater shale content. The magnetic-susceptibility logs show variations for gneiss that coincide with zones identified by drill cuttings and core having magnetic and pyritic mineralogy, and other zones not seen in the drill cuttings or core.

The lithology was visually identified by the optical image in the open wellbore. The optical logs in the gneiss show light and dark mineral banding. The acoustic image in the non-fractured gneiss shows little change in the hardness or the wave absorption properties of the bands. The optical logs in the quartzite show no color banding and are generally lighter in color than the gneiss and the dolostone. The acoustic image in the non-fractured quartzite, like the gneiss, shows little variation. The optical logs in the dolostone show alternating massive (tens of feet thick) and thinly bedded zones with the color varying from white to very dark. The acoustic image shows changes in the thinly bedded zones within the dolostone, indicating a difference in the hardness or wave absorption between the light and dark bedding zones.

\section{Structural Features}

Structural features, including foliation, bedding, and fractures, were identified in each logged well through the analysis of the suite of geophysical logs collected in each well. OTV and ATV logs were used to identify the fabric (foliation and bedding) and fractures.

\section{Bedrock Fabric}

The fabric in the wellbore was determined by using the OTV and ATV logs to identify the orientations of foliations in the gneiss, bedding planes in the dolostone, and lithologic and stratigraphic contacts. The bedrock fabric orientation within the gneiss reflects the regional northeast-southwest structural trend, as well as localized folding. The fabric dip angles vary from near horizontal to over 80 degrees. The distribution and orientation of fabric features (foliation and bedding) are presented as tadpole plots within the suite of geophysical logs for each of three selected wells (appendix 1, figs. 1-1 through 1-3).

\section{Fractures}

The fractures penetrated by the wellbore were characterized by using the optical, acoustic, and caliper logs, along with the location of fractures noted in the test wells at time of drilling. The fracture log is presented as a tadpole plot of the fractures oriented to magnetic north. The fracture azimuth and dip amplitude were determined using the OTV and ATV logs. Large variations in the fracture azimuth were seen in the fractures. The fracture dip amplitudes vary from near horizontal to greater than 85 degrees. Many fractures were oriented along or orthogonal to foliation and bedding. Fracture depths were confirmed using the caliper log. The distribution and orientation of fractures are presented as tadpole plots within the suite of geophysical logs for each well (appendix 1).

\section{Flow Zones}

The flow zones penetrated by the wells were characterized by the integrated analysis of the image, caliper, fluidproperty, and flow logs, drilling logs, and single-well aquifer test data. The total wellbore transmissivity of the wells was estimated through analysis of the single-well aquifer test data using the Cooper-Jacob method or through an empirical relation between transmissivity and specific capacity developed during this study. The transmissivity and hydraulic head of the individual fracture zones penetrated by the wells was estimated by analysis of the total wellbore transmissivity and the flow logs under ambient and quasi-steady-state pumping conditions using the Thiem equation.

\section{Distribution of Flow Zones and Wellbore Flow}

The distribution of fracture-flow zones (transmissive fracture zones) and wellbore flow in the test wells and residential wells was determined by the integrated analysis of the caliper, OTV, ATV, fluid-resistivity, temperature, and flow logs. The caliper, OTV, and ATV logs were used to locate points within the wellbore where the borehole wall appeared to be competent. These points enabled precise positioning of the flowmeter and helped to ensure that the flow diverter would fit snugly against the borehole wall, thus diverting the maximum amount of borehole flow channeled through the flowmeter measurement chamber. Changes in the fluid resistivity, temperature, and flow logs collected under ambient and either pumping or recovery conditions were then analyzed along with the fracture data from the image and caliper logs to identify water-bearing fractures penetrated by the wellbore. One or more fractures within each zone typically were identified as transmissive 
fractures that contributed to the measured ambient and pumped flows. Transmissive fractures are shown in blue on the tadpole plots within the suite of geophysical logs in appendix 1 (figs. 1-1 through 1-3).

Many flow zones were associated with subhorizontal to shallow-dipping fractured zones or high-angle dipping fractures. Most of the water-bearing fractures were at depths of less than $300 \mathrm{ft}$, although some water-bearing fractures were identified as deep as $500 \mathrm{ft}$ (see fig. 5). The locations of the water-bearing fractures in the drilled monitoring wells enabled GSC to subsequently design a multi-port well liner (Flute system) for each well to monitor heads at individual fracture zones and to allow for discrete-zone sampling of VOCs. Moreover, identifying the transmissive fracture zones in the 23 residential wells, now abandoned, enabled the utilization of these wells as additional monitoring wells. Results of the analysis of geophysical logs were used to guide well reconstruction in order to isolate individual or sets of fracture zones.

\section{Estimates of Total Wellbore Transmissivity}

The total wellbore transmissivity was estimated for the wells using discharge and transient-drawdown data with AQTESOLVE software to visually match the straight-line solution of the Cooper-Jacob method (Cooper and Jacob, 1946). The specific capacities [discharge (Q) divided by drawdown (s)] of these analyzed wells were regressed against their respective transmissivity estimates to establish a relation that could be used to estimate the wellbore transmissivity for those wells in which sufficient transient drawdown data were not available. The empirical relation between specific capacity and transmissivity for 29 selected wells at the Shenandoah Road Superfund Site was log-normally distributed and, therefore, required a log-log plot to produce a normal distribution for transmissivity. The equation of the best-fit trendline (fig. 2) is

$$
T=122.73(Q / s-0.049)^{1.0082},
$$

where

$$
\begin{aligned}
& T \quad \text { is transmissivity, in feet squared per } \\
& \text { day, and } \\
& Q / s \quad \text { is specific capacity, in gallons per } \\
& \text { minute per foot of drawdown, } \\
& \text { measured after } 30 \text { minutes } \\
& \text { of pumping. }
\end{aligned}
$$

The correction factor 0.049 was subtracted from each 30-minute drawdown to account for the effects of wellbore storage on the value of calculated transmissivity from shortduration single-well aquifer tests such as these. The coefficient of determination $\left(\mathrm{R}^{2}\right)$ is 0.76 . The equation of best fit for the Shenandoah Road transmissivity data in relation to specific capacity data is comparable to similar equations compiled by Srivastav and others (2007) for various types of fractured rock. Transmissivities and specific capacities were calculated from single-well aquifer test results for 29 of the 43 wells logged, and these data were used to create a predictive relation between overall transmissivity and specific capacity for the bedrock in this area (fig. 2). Wellbore transmissivity estimates ranged from 0.36 to $370 \mathrm{ft}^{2} /$ day, and specific capacities ranged from 0.03 to $2.1(\mathrm{gal} / \mathrm{min}) / \mathrm{ft}$. Two of the smallest estimated transmissivities, for wells Du-3265 $\left(0.93 \mathrm{ft}^{2} / \mathrm{d}\right)$ and Du-3232 $\left(0.36 \mathrm{ft}^{2} / \mathrm{d}\right)$, were eliminated from this dataset and figure 2 because their estimates were controlled by wellbore storage and not by aquifer properties. Ambient water levels, pumping rates, specific capacities, and transmissivities for the

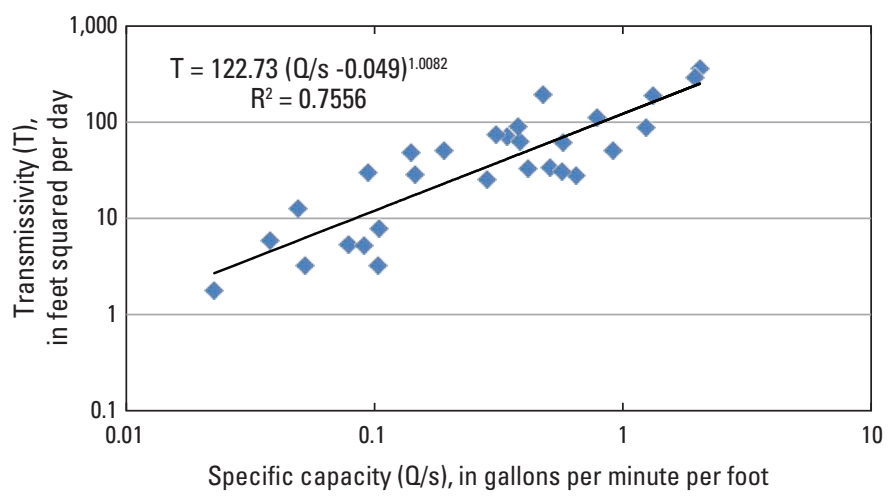

Figure 2. Log-Log plot of specific capacity at 30 minutes versus transmissivity for logged wells at the Shenandoah Road National Superfund Site, Dutchess County, N.Y.

Shenandoah Road National Superfund Site wells are listed in table 3 .

\section{Estimates of Flow-Zone Transmissivity and Head}

The transmissivity and hydraulic head of the flow zones were estimated by the flow-log analysis method described by Paillet (1998 and 2000). In this method, a best-fit match is developed between measured and model-calculated ambient and pumped flows by iterative adjustment of transmissivities and heads of individual flow zones in a numerical or analytical model. In similar hydrogeologic settings and wellbore conditions, the flow-log analysis method was shown to generally detect and quantify the hydraulic properties of flow zones whose transmissivities were within two orders of magnitude of the most transmissive zone penetrated in each given well (Paillet,1998 and Williams, 2008). A conceptual model of two flow zones in a well with heads under ambient and pumped conditions is shown in figure 3.

The analytical model FLASH (Flow Log Analysis of Single Holes; Day-Lewis and others, 2011) was used to solve for fracture-zone transmissivities and hydraulic heads. The FLASH model code, which is based on a multi-layer, analytical solution for steady-state radial flow to a single borehole 


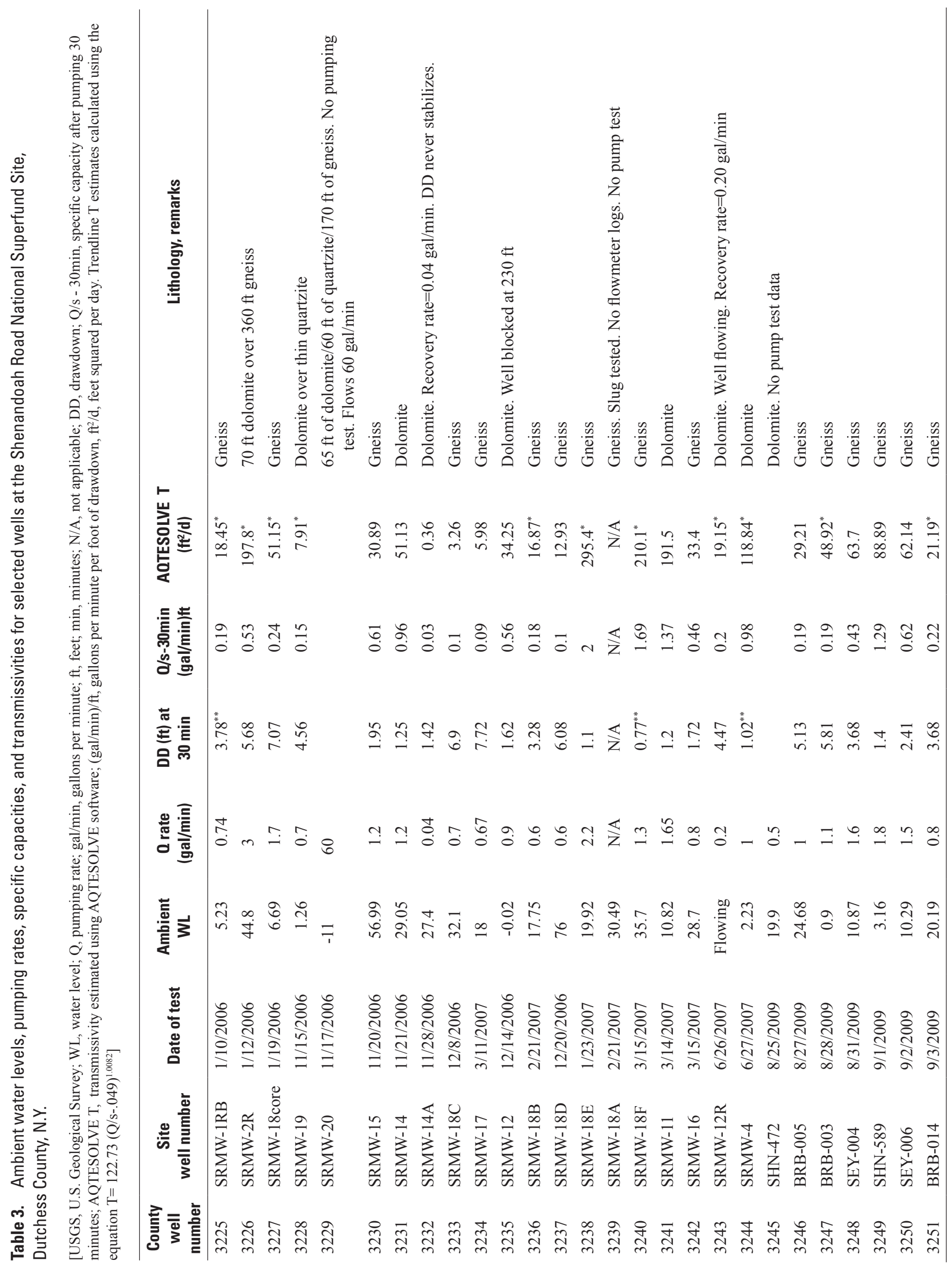




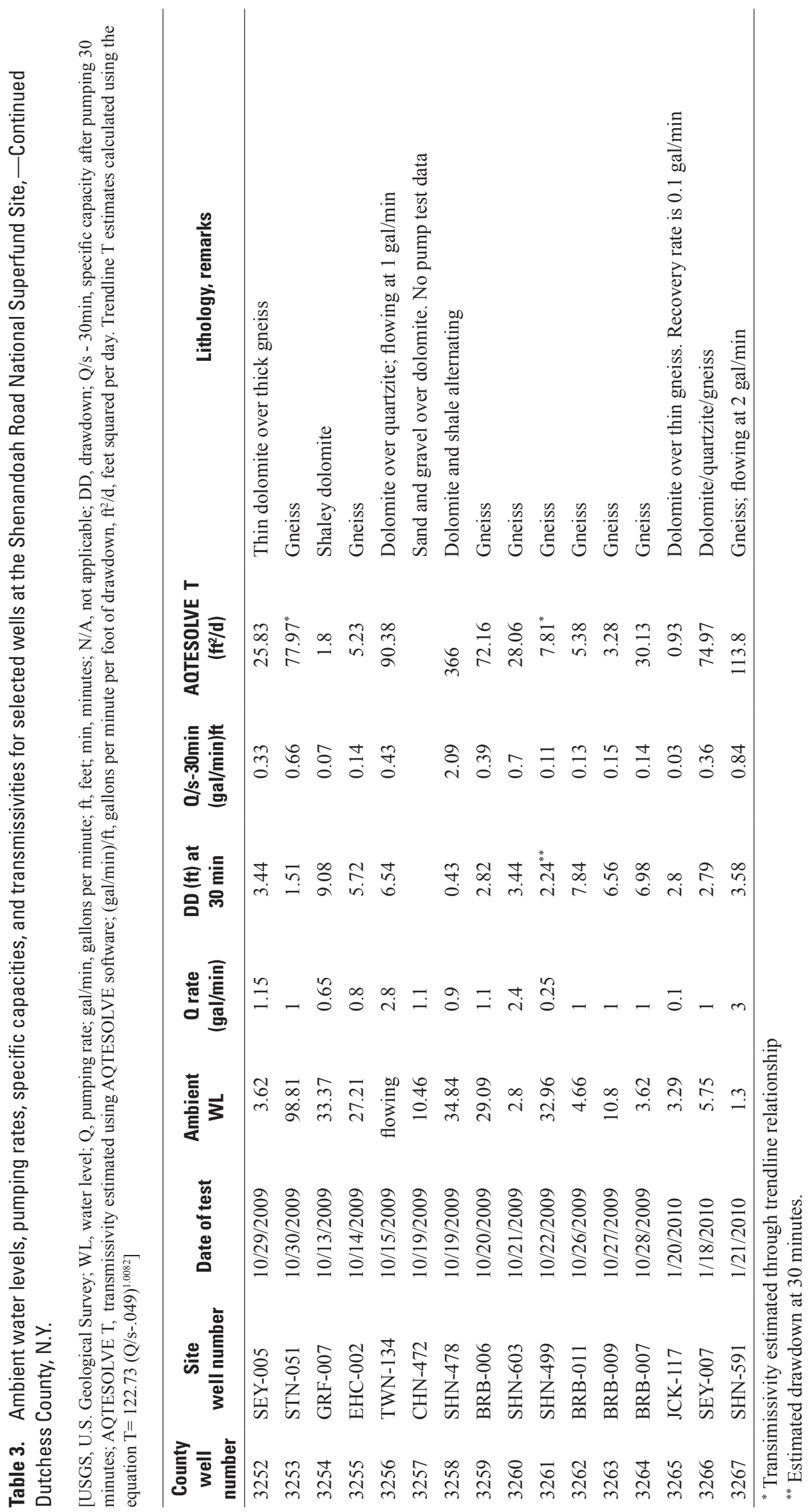


A. Flowmeter $\log$

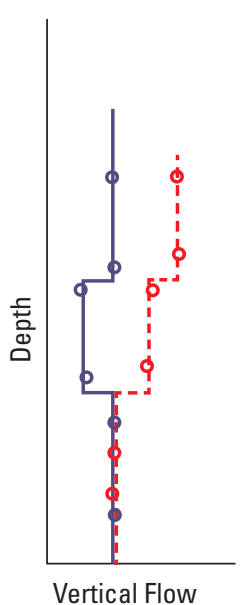

B. Ambient condition

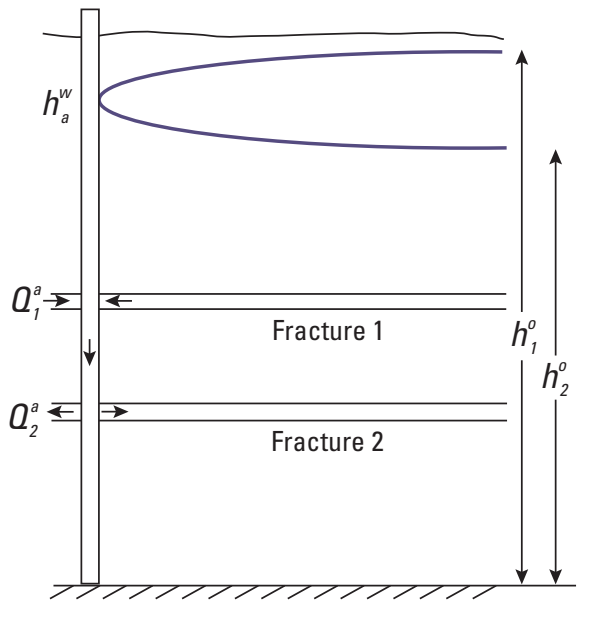

\section{Stressed (pumped) condition}

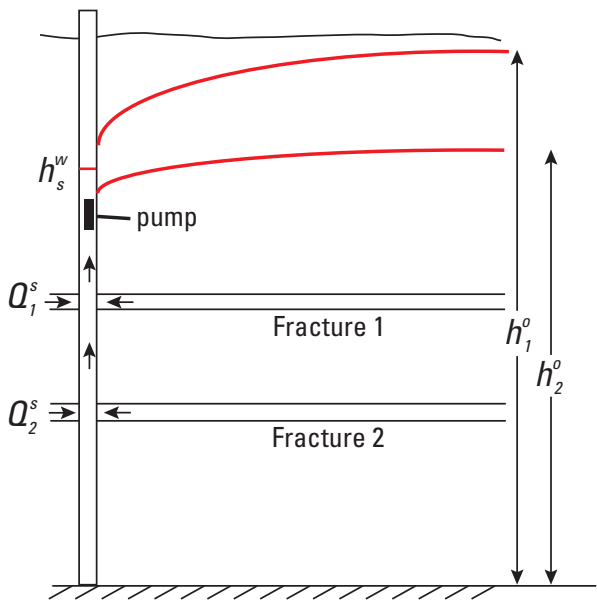

Figure 3. Conceptual model of two flow zones in a well with heads under ambient and pumped conditions.

(the Thiem equation), is embedded within Microsoft Excel. The code solves a series of Thiem equations (fig. 3) that assume radial flow under equilibrium conditions. The series includes equations to represent the flow to (or from) the borehole from each flow zone under ambient and stressed conditions. This approach is easily implemented in Excel and facilitates the use of the Excel solver for automated model calibration. However, this approach requires a radius of influence $\left(r_{0}\right)$ to solve for transmissivity or a total transmissivity to solve for $r_{0}$. The total wellbore transmissivity was estimated for each well on the basis of the Cooper-Jacob method or empirical relation as previously discussed.

The analytical model used to iteratively solve for individual fracture-zone transmissivities is a version of the Thiem equation.

$Q_{i}^{a}=\frac{2 \pi T_{i}^{\text {factor }} T^{\text {total }}\left(h_{w}^{a}-h_{i}^{0}\right)}{\ln \left(\frac{r_{0}}{r_{w}}\right)}$ and

$Q_{i}^{s}=-\frac{2 \pi T_{i}^{\text {factor }} T^{\text {total }}\left(h_{w}^{s}-h_{i}^{0}\right)}{\ln \left(\frac{r_{0}}{r_{w}}\right)}$,

where,

$\begin{array}{cl}Q_{i}^{a} & \text { is the ambient flow for zone } i, \\ Q_{i}^{s} & \text { is the stressed flow for zone } i, \\ T_{i}^{\text {factor }} & \text { is the fraction of total transmissivity in zone } i, \\ h_{w}^{a} & \text { is the water level in the well under ambient } \\ & \quad \text { conditions, } \\ h_{w}^{s} & \quad \text { is the water level in the well under stressed } \\ r_{w} & \quad \text { is the radius of the well, } \\ r_{0} & \text { is the radius of influence, } \\ h_{i}^{0} & \text { is the far-field head in zone } i, \text { and } \\ T^{t o t a l} & \text { is the total transmissivity for the well. }\end{array}$

The model-calculated wellbore flows and the estimated transmissivity and hydraulic-head differences for the individual fracture zones are presented with the suite of geophysical logs for each well in appendix 1.

The distribution of the transmissivity of the individual water-bearing fracture zones in the logged wells at the Shenandoah Road National Superfund Site appears to be approximately log-normal, as seen in a frequency distribution plot in figure 4. The transmissivities of 95 individually identified fracture zones ranged from 0.25 to $340 \mathrm{ft}^{2} / \mathrm{d}$, with a median value of $6.7 \mathrm{ft}^{2} / \mathrm{d}$. Most of the individual fracture zones are present at depths of $300 \mathrm{ft}$ or less as shown in figure 5. Figure 5 also shows that most of the transmissivities for fractures up to $300 \mathrm{ft}$ deep range over two orders of magnitude - generally from 1 to $100 \mathrm{ft}^{2} / \mathrm{d}$. The three highest fracture-zone

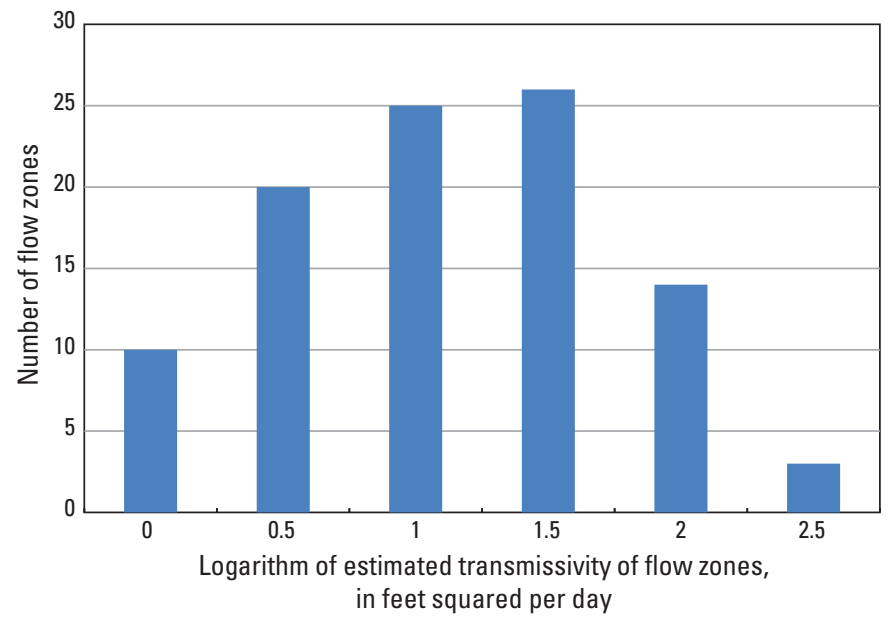

Figure 4. Frequency distribution of estimated transmissivity of flow zones penetrated by wells at the Shenandoah Road National Superfund Site, Dutchess County, N.Y. 


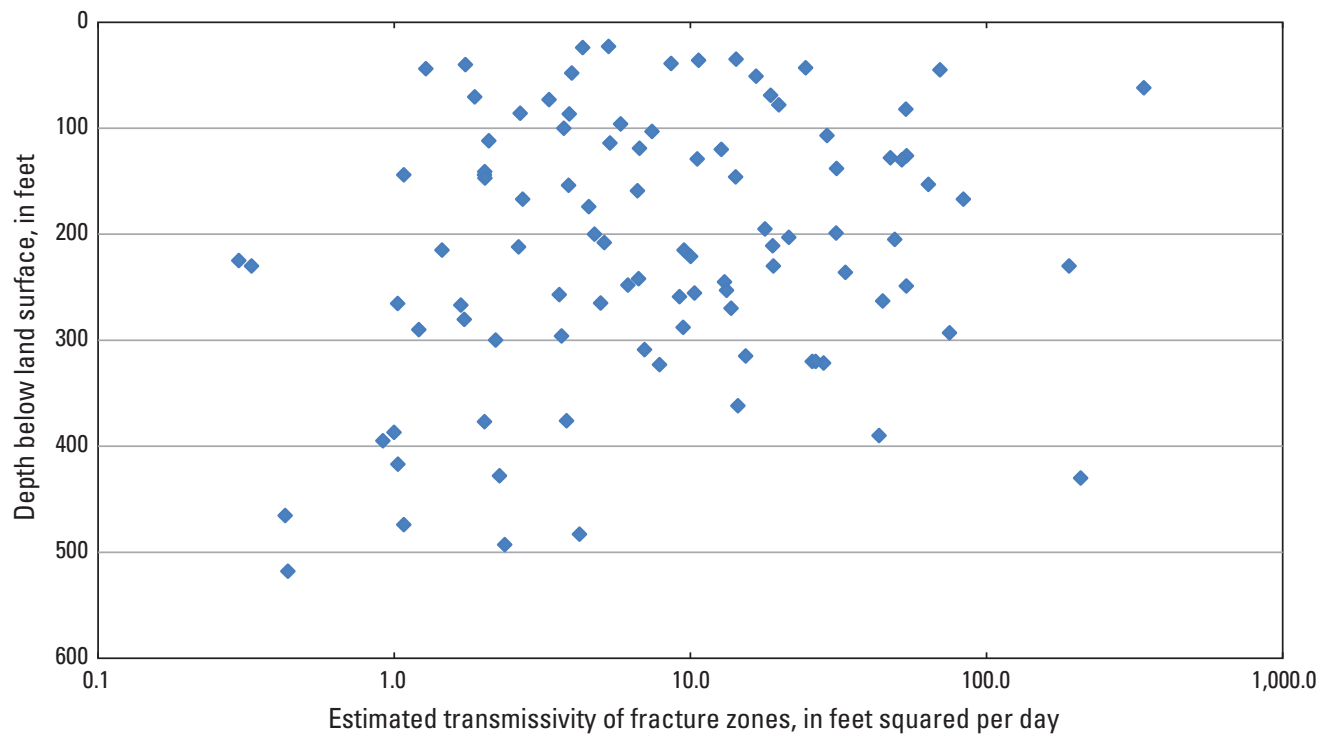

Figure 5. Depths of individual fracture zones versus estimated fracture zone transmissivity for wells logged at the Shenandoah Road National Superfund Site, Dutchess County, N.Y.

transmissivities (340, 190, and $\left.208 \mathrm{ft}^{2} / \mathrm{d}\right)$ display a wide range of depths - 62, 230, and $430 \mathrm{ft}$, respectively (fig. 5).

The composite hydraulic head of a well is the transmissivity-weighted average of the individual fracture-zone heads (Bennet and others, 1982). The difference between estimated individual fracture-zone heads and the composite head in each well ranged from less 0.01 to more than $10 \mathrm{ft}$. The relation between fracture-zone hydraulic-head differences estimated using the analytical model and those measured through discrete-zone monitoring installations is presented in figure 6 .

Some significant error in this comparison arises from the fact that the estimated heads are representative of the time of logging, whereas individual head measurements of fracture-zone heads were made though Flute liner ports or in reconstructed residential wells, often at a different time of the

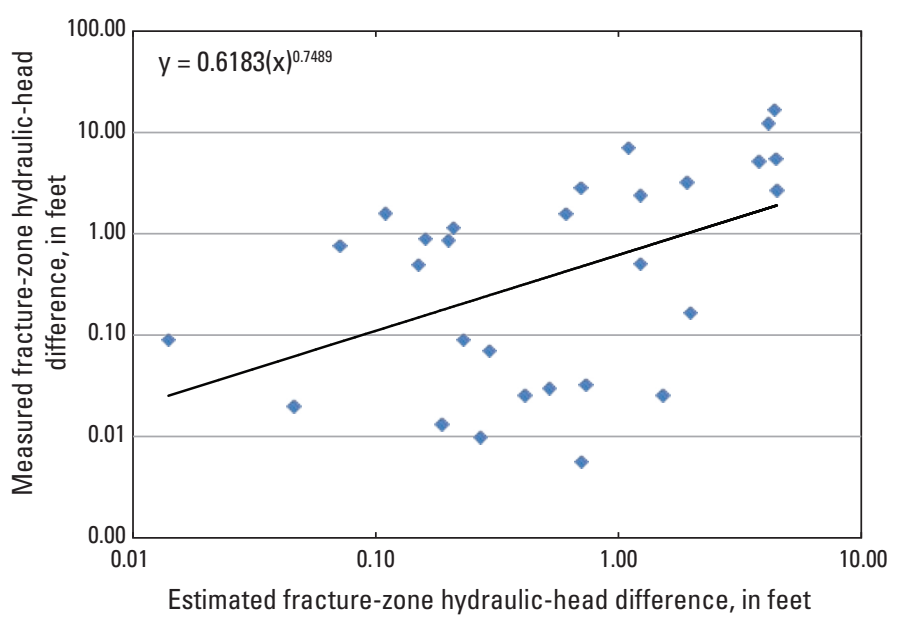

Figure 6. Comparison of estimated hydraulic-head difference to measured hydraulic-head difference for flow zones in logged wells at the Shenandoah Road National Superfund Site, Dutchess County, N.Y. year than the flow logging. Composite wellbore and fracturezone heads on Shenandoah Mountain display seasonal swings on the order of tens of feet and respond rapidly to recharge events, thus compounding the problem of comparing estimated and measured heads. Given these limitations, it appears that the flow-log method generally provides an order of magnitude estimate for the difference between fracture-zone hydraulic heads and the composite head.

\section{Online Geophysical Log Archive}

The USGS New York Water Science Center has developed an online geophysical log archive where the logs and $\log$ analysis of the Shenandoah Road Superfund site wells, as well as many others throughout the State, can be viewed or downloaded. The URL for the website is http://ny.water.usgs. gov/maps/geologs/.

The locations of the Shenandoah Road National Superfund Site wells are shown on the index map. The user can zoom-in to the well cluster located just east of Fishkill, N.Y., to expand the view of the wells logged. Clicking on an individual well will bring up a menu of the available log formats, which are LAS, PDF, and WellCad Reader. WellCad Reader is available online free of charge at http://www.alt.lu/ downloads.htm.

\section{Summary}

From 2006 through 2010, the U.S. Geological Survey collected geophysical logs for 20 test wells and 23 residential wells at the Shenandoah Road National Superfund Site in Dutchess County, New York, for a study conducted in cooperation with the U.S. Environmental Protection Agency, Region 2, as part of an Interagency Agreement to provide geophysical 
and hydrogeologic technical support. The logs collected included caliper, gamma, acoustic and optical televiewer, deviation, electromagnetic-induction, magnetic-susceptibility, fluid-property, and vertical flow under ambient and pumped conditions. The geophysical logs were analyzed, along with drilling logs, to characterize the lithology, fabric, fractures, and flow zones penetrated by the wells. Flow logs and singlewell aquifer test data were analyzed to estimate the transmissivity and hydraulic heads of the individual fracture zones penetrated by the wells. The results of the geophysical-log analysis were used in the design of discrete-zone monitoring installations in the test wells and selected residential wells.

Most of the test and residential wells penetrate the Hudson Highlands Complex gneisses or Wappinger Group dolostones. Some wells penetrate both the dolostone and gneiss. The bedrock fabric, which reflects the regional northeastsouthwest structural geology, as well as localized folding, includes foliations in the gneiss and bedding in the dolostone. Many fractures were oriented along the bedrock fabric, and many others are orthogonal to the fabric.

Total wellbore transmissivity of the wells was estimated from short-term, single-well aquifer test data through the use of the Cooper-Jacob analytical solution. An empirical relation was established to estimate total wellbore transmissivity from specific-capacity data for those wells with insufficient transient drawdown measurements. Wellbore transmissivity estimates ranged from 0.36 to 370 feet squared per day ( $\mathrm{ft}^{2} /$ day), and specific capacities ranged from 0.03 to 2.1 gallons per minute per foot $[(\mathrm{gal} / \mathrm{min}) / \mathrm{ft}]$.

Transmissivity and hydraulic heads of individual fracture zones were estimated from the total wellbore transmissivity and flow logs through use of an analytical model based on the Thiem equation. The model-estimated transmissivity of 95 fracture zones delineated in the 43 wells ranged from 0.25 to $340 \mathrm{ft}^{2} / \mathrm{d}$, with a median value of $6.7 \mathrm{ft}^{2} / \mathrm{d}$. The differences between model-estimated fracture-zone heads and the composite heads in each well ranged from less 0.01 to more than $10 \mathrm{ft}$. Flow-log analysis generally provided an order of magnitude estimate for the fracture-zone hydraulic-head difference on the basis of a comparison of estimated and measured values.

\section{Selected References}

Bennett, G.D., Kontis, A.L., and Larson, S.P., 1982, Representation of multiaquifer well effects in three-dimensional ground-water flow simulation: Ground Water, v. 20, no. 3, p. 334-341.

Connally, G.G., 1980, Reconnaissance surficial geologic map of the Hopewell Junction 7.5-mi. quadrangle: New York State Geological Survey Open-File Report no.2gk561, 1 sheet, $1: 24,000$.
Connally, G.G., and Sirkin, L.A., 1986, Woodfordian ice margins, recessional events, and pollen stratigraphy of the mid-Hudson valley, in Cadwell, D.H., ed., The Wisconsinan stage of the First Geological District, eastern New York: New York State Museum Bulletin no. 455, p. 50-72.

Cooper, H.H., Jr., and Jacob, C.E., 1946, A generalized graphical method for evaluating formation constants and summarizing well-field history: American Geophysical Union Transactions, v. 27 , no. 4 , p. 526-534.

Dana, J.D., 1872, Green Mountain geology - the quartzite of Poughquag, Dutchess County, New York: American Journal of Science, Series 3, v. 3, p. 253-256.

Dana, J.D., 1879, On the Hudson River age of the Taconic schists and on the dependent relations of the Dutchess County and western Connecticut limestone belts: American Journal of Science, Series 3, v.17, p. 375-388 and v.18, p. 61-64.

Day-Lewis, F.D., Johnson, C.D., Paillet, F.L., and Halford, K.J., 2011, A Computer Program for Flow-Log Analysis of Single Holes (FLASH): Groundwater, V. 49, no. 6, p. 926-931 accessed January 11, 2013 at http://water.usgs.gov/ ogw/flash/FLASH-v1.0.pdf.

Dwight, W.B., 1887, Recent explorations in the Wappinger Valley limestones of Dutchess County, NY, No. 6: American Journal of Science, Series 3, v. 34, p. 139-153.

Fisher, D.W., 1968, Draft geologic map of the Hopewell Junction 7.5-min. quadrangle: New York State Geological Survey Open-File No. 1gG744, 3 sheets, 1:24,000 scale.

Fisher, D.W., 1977, Correlation of the Hadrynian, Cambrian, and Ordovician rocks in New York State: New York State Museum and Chart Series no. 25, 75 p., 5 sheets.

Fisher, D.W., Isachsen, Y.W., and Rickard, L.V., 1970, Geologic map of New York: New York Museum and Science Service Map and Chart Series No. 15, 5 sheets, 1:250,000 scale.

Fisher, D.W., and McLelland, J.M., 1975, Stratigraphy and structural geology in the Amenia-Pawling valley, Dutchess County, New York, in Ratcliffe, N.M., ed., Guidebook for field trips in western Massachussetts, northern Connecticut, and adjacent areas of New York: New England Intercollegiate Geological Conference, 67th annual meeting, October 10-12, 1975, Trip C-10, p. 280-312.

Fisher, D.W., and Warthin, A.S. Jr., 1976, Stratigraphic and structural geology in western Dutchess County, New York, in Johnsen, J.H., ed., Guidebook to field excursions: 48th Annual Meeting of the New York State Geological Association, October 15-17, 1976, Vassar College, Poughkeepsie, New York, Trip B-6, p B6-1- B6-36. 
Fluhr, T.W., 1931, Geology of the Fishkill area, New York-a report prepared for the Board of Water Supply, City of New York: New York State Geological Survey Open-File No. 6mF302, 8 p.

Gerber, R.G., 1982, Reconnaissance surficial geologic map of the Hopewell Junction 7.5-min. quadrangle: Unpublished map on file with the U.S. Geological Survey, Troy, N.Y., $1: 24,000$ scale.

Gordon, C.E., 1911, Geology of the Poughkeepsie Quadrangle: New York State Museum Bulletin No. 148, 121 p.

Groundwater Sciences Corporation, 2012, Shenandoah Road groundwater contamination Superfund site remedial investigation report: Groundwater Sciences Corp., Harrisburg, Pa., v. 1 (text and tables), 222 p., v. 2 (figures, plates, and appendices), 57 p., 8 CD-ROMs.

Helenek, H.L., 1972, Bedrock geology of the Hopewell Junction, NY 7.5-min. quadrangle - a preliminary report: New York State Geological Survey Open-File No.1g274, 13 p., 1 sheet, 1:24,000 scale.

Helenek, H.L., and Mose, D., 1976, Structure, petrology, and geochronology of the Precambrian rocks of the Hudson Highlands, in Johnsen, J.H., ed., Guidebook to field excursions: $48^{\text {th }}$ Annual Meeting of the New York State Geological Association, October 15-17, 1976, Vassar College, Poughkeepsie, New York, Trip B-1, p B1-1 - B1-27.

Hess, A.E., 1982, A heat-pulse flowmeter for measuring low velocities in boreholes: U.S. Geological Survey Open-File Report 82-699, 44 p.

Holzwasser, F., 1926, Geology of Newburgh and vicinity: New York State Museum Bulletin no. 270, 95 p.

Huntley, David, Nommensen, Roger, and Steffey, Duane, 1992, The use of specific capacity to assess transmissivity in fractured-rock aquifers: Ground Water, v. 30, no. 3, p. 396-402.

Johnson, C.D., Day-Lewis, F.D., Paillet, F.L., and Halford, K.J., 2009, FLASH-a program for flow log analysis of single holes (poster): EPA National Ground Water Forum and U.S. Geological Survey Toxics Meeting in San Diego, Calif., January 2009.

Keys, W.S., 1990, Borehole geophysics applied to groundwater investigations: U.S. Geological Survey Techniques of Water-Resources Investigations, book 2, chap. E2, p. 150.

Knopf, E.B., 1946, Stratigraphy of the lower Paleozoic rocks surrounding Stissing Mountain, Dutchess County, New York (abs.): Geological Society of America Bulletin, v.57, p. 1211-1212.
Moore, R.B., LaFleur, R.G., and others, 1982, Geohydrology of the valley-fill aquifer in the Sprout and Fishkill Creeks area, Dutchess County, N.Y.: U.S. Geological Survey OpenFile Report 82-81, 6 sheets, 1:24,000 scale.

Offield, T.W., 1962, Geology reconnaissance maps, southern portion of the Hopewell Junction 7.5-min. quadrangle: New York State Geological Survey Open-File No.1gB660, 2 sheets, 1:24,000 scale.

Paillet, F.L., 1998, Flow modeling and permeability estimation using borehole flow logs in heterogeneous fractured formations: Water Resources Research, v. 34, no. 5, p. 997-1010.

Paillet, F.L., 2000, A field technique for estimating aquifer parameters using flow log data: Ground Water, v. 38, no. 4, p. 510-521.

Paillet, F.L., 2001, Hydraulic head applications of flow logs in the study of heterogeneous aquifers: Groundwater, v. 39, no. 5, p. 667-675.

Ratcliffe, N.M., and Burton, W.C., 1990, Bedrock geologic map of the Poughquag quadrangle, New York: U.S. Geological Survey Quadrangle Map GQ-1662, scale 1:24,000.

Reynolds, R.J., and Calef, F.J., III., 2010, Hydrogeologic data update for the stratified-drift aquifer in the Sprout and Fishkill Creek valleys, Dutchess County, New York: U.S. Geological Survey Scientific Investigations Map 3136, 4 sheets, 1:24,000, accessed January 11, 2013, at http:// pubs.usgs.gov/sim/3136.

Simmons, E.T., Grossman, I.G., and Heath, R.C., 1961, Ground-water resources of Dutchess County, New York: New York State Department of Conservation Bulletin GW-43, 82 p.

Snavely, D.S., 1980, Ground-water appraisal of the FishkillBeacon area, Dutchess County, New York: U.S. Geological Survey Open-File Report 80-437, 14 p.

Srivastav, S.K., Lubczynski, M.W., and Biyani, A.K., 2007, Upscaling of transmissivity derived from specific capacity - a hydrogeomorphological approach applied to the Doon Valley aquifer system in India: Hydrogeology Journal, v. 15 , p. $1251-1264$.

U.S. Environmental Protection Agency, 2001, NPL site narrative for Shenandoah Road groundwater contamination: U.S. Environmental Protection Agency Region 2, accessed January 11, 2013, at http://www.epa.gov/superfund/sites/ $\mathrm{npl} /$ nar1628.htm.

U.S. Environmental Protection Agency, 2010, Shenandoah Groundwater Contamination Superfund Site, New York factsheet: U.S. Environmental Protection Agency Region 2, accessed January 11, 2013, at http://www.epa.gov/region2/ superfund/npl/0204269c.pdf. 
Walcott, C.D., 1891, Overlap relations at the base of the Paleozoics in the northern Appalachians: Bulletin of the Geological Society of America, v. 2, p. 163-164.

Williams, J.H., 2008, Flow-log analysis for hydraulic characterization of selected test wells at the Indian Point Energy Center, Buchanan, New York: U.S. Geological Survey Open-File Report 2008-1123, 30 p., accessed January 11, 2013, at http://pubs.usgs.gov/of/2008/1123.

Williams, J.H., and Johnson, C.D., 2000, Borehole-wall imaging with acoustic and optical televiewers for fractured-bedrock aquifer investigations, in Proceedings of the 7th minerals and geotechnical logging symposium: Golden, Colo., Minerals and Geotechnical Logging Society, p. 43-53.

Williams, J.H., and Lane, J.W., 1998, Advances in borehole geophysics for groundwater investigations: U.S. Geological Survey Fact Sheet 002-98, 4 p.

Young, S.C., and Pearson, H.S., 1995, The electromagnetic borehole flowmeter-description and application: Ground Water Monitoring and Remediation Review, v. 15, no. 4, p. $138-147$. 


\section{Appendix 1. Geophysical Log Analysis of Three Selected Wells at the Shenandoah Road National Superfund Site, Dutchess County, N.Y.}





\section{Appendix 1. Geophysical Log Analysis of Three Selected Wells at the Shenandoah Road National Superfund Site, Dutchess County, N.Y.}

The geophysical logs and analysis of the logs for three selected wells at the Shenandoah Road National Superfund site in Dutchess County, New York, are presented below. Well Du-3246 (BRB-5) is a contaminated residential well that was logged by the U.S. Geological Survey (USGS) and later converted for monitoring purposes by Groundwater Sciences Corporation (GSC). Wells Du-3241 (SRMW-11) and Du-3230 (SRMW-15) are test wells that were drilled for the purpose of the Remedial Investigation/Feasability Study (RI/FS) investigation and were later fitted with multiple discrete-zone monitoring systems to facilitate the monitoring of head and water quality at individual flow zones.

\section{Du-3246 (BRB-5)}

Well Du-3246 is located downslope from the source area for the Shenandoah Road National Superfund site. The well is 276 feet (ft) deep and is completed in Hudson Highlands Complex gneisses. The bedrock fabric identified on the optical televiewer log generally dips less than 30 degrees with variable dip directions. Fractures identified on the acoustic and optical televiewers are sparse between 90 and $240 \mathrm{ft}$. Open fractures appear to be present at 36, 86, 242, and $259 \mathrm{ft}$. Iron staining, clearly visible at the $86-$ and $259-\mathrm{ft}$ fractures, indicates possible fluid movement and is indicative of a transmissive fracture. The ambient temperature log shows a gradient less than the geothermal gradient, which is consistent with the presence of wellbore flow. The fluid-conductivity $\log$ shows a deflection at the 86 -ft fracture zone under ambient and pumped conditions, indicative of water inflow. The flowmeter measurements and interpreted flow under ambient and pumped conditions indicate upflow under both conditions, starting from the fracture zone at $259 \mathrm{ft}$ with small additional inflows from zones at $242 \mathrm{ft}$ and $86 \mathrm{ft}$. All of the upflow exits the wellbore at the fracture zone at $36 \mathrm{ft}$ under ambient conditions, and a fraction of the upflow exits at this fracture zone under pumped conditions. The estimated transmissivities from the flow-log analysis are 9.2 feet squared per day $\left(\mathrm{ft}^{2} / \mathrm{d}\right)$ for the $259-\mathrm{ft}$ fracture, $6.7 \mathrm{ft}^{2} / \mathrm{d}$ for the $242-\mathrm{ft}_{\text {zone, }} 2.7 \mathrm{ft}^{2} / \mathrm{d}$ for the $86-\mathrm{ft}$ zone, and $10.7 \mathrm{ft}^{2} / \mathrm{d}$ for the $36-\mathrm{ft}$ zone. The estimated heads at each flow zone indicate similar heads are present at the two lowermost zones ( 242 and $259 \mathrm{ft}$ ), a slightly lower head at the $86-\mathrm{ft}$ zone, and a much lower head at the $36-\mathrm{ft}$ zone. The head differences estimated through flow analysis are consistent with those measured following reconstruction of the well into a dual-interval monitoring well.

\section{Du-3241 (SRMW-11)}

Well Du-3241 is on Townsend Road, just north of the eastbound lane of Interstate 84 and northeast of the Shenandoah Road contamination source. This test well is $500 \mathrm{ft}$ deep and penetrates dolostones of the Poughquag Quartzite of the Wappinger Group and terminates in the Hudson Highlands Complex gneisses. The reported blown yield of the well was 50 gallons per minute (gal/min). Increases in blown yield were reported from a fracture near $125 \mathrm{ft}$ (below land surface) and multiple fractures between 300 and $450 \mathrm{ft}$. The bedding in the dolostones identified on the optical televiewer log generally dips to the northeast at less than 30 degrees. The foliation in the gneiss generally dips east-southeast at 30 to 60 degrees. Fractures identified on the acoustic and optical televiewers are sparse. Open fractures appear to be present at 126, 236, 293, 321,387 , and $474 \mathrm{ft}$. The ambient temperature shows a change in slope at the $321-\mathrm{ft}$ fracture zone, indicating a decrease in ambient flow. The ambient and pumped fluid-conductivity and temperature logs depart from each other between the 126-ft fracture zone and the $293-\mathrm{ft}$ fracture zone, indicating a possible change in flow direction. Subtle slope changes on the ambient and pumped fluid-conductivity logs at the 387- and 474-ft zones indicate the possibility of slight inflows. The flowmeter measurements and interpreted flow under ambient conditions indicate downward flow from the 126-ft fracture zone. The downward flow slightly decreases at the $236-\mathrm{ft}$ fracture zone, slightly increases at the 293 -ft fracture zone, and finally exits at the $321-\mathrm{ft}$ fracture. The ambient flowmeter log indicates no measurable flow between $321 \mathrm{ft}$ and the bottom of the well. Wellbore flow is reversed when the well is pumped at $1.6 \mathrm{gal} / \mathrm{min}$. The pumped flow log indicates very slight upward flow starting at the 474-ft zone with large increases at 293- and 126-ft zones and a small increase at the 236-ft zone. The estimated fracture transmissivities from the flow-log analysis are $54 \mathrm{ft}^{2} / \mathrm{d}$ for the $126-\mathrm{ft}$ zone, $33 \mathrm{ft}^{2} / \mathrm{d}$ for the $236-\mathrm{ft}$ zone, $75 \mathrm{ft}^{2} / \mathrm{d}$ for the $293-\mathrm{ft}$ zone, $28 \mathrm{ft}^{2} / \mathrm{d}$ for the $321-\mathrm{ft}$ zone, and $1 \mathrm{ft}^{2} / \mathrm{d}$ or less for the 387 - and $473-\mathrm{ft}$ zones. The estimated heads at individual flow zones indicate lower heads at the 321- and 236-ft zones and higher heads at the 293- and 126-ft zones. The head differences estimated through flow analysis generally were consistent with those measured following installation of the multiple discrete-monitoring system in the test well.

\section{Du-3230 (SRMW-15)}

Well SRMW-15 (DU-3230) is a test well located on the south side of Shenandoah Road at the nose of Shenandoah Mountain. The well is $500 \mathrm{ft}$ deep and penetrates Hudson Highlands Complex gneisses. Total blown yield reported for the well was $20 \mathrm{gal} / \mathrm{min}$ with essentially all of the yield from 
multiple fractures near $350 \mathrm{ft}$ and only a small amount from a fracture near $200 \mathrm{ft}$. The foliation in the gneiss identified on the optical televiewer above $260 \mathrm{ft}$ is variable. Below $260 \mathrm{ft}$, the foliation generally dips northwest to east at less than 60 degrees. Fractures identified on the acoustic and optical televiewers generally dip to the southeast or northwest at variable angles. Open fractures appear to be present at 86, 119, 200, 233, 323, and $362 \mathrm{ft}$. The ambient fluid-conductivity log indicates that the fluid conductivity of the wellbore water is significantly higher [up to 2,300 microsiemens per centimeter $(\mu \mathrm{S} / \mathrm{cm})]$ above the $200-\mathrm{ft}$ zone than below the zone (about $230 \mu \mathrm{S} / \mathrm{cm}$ ). Under pumping conditions, the change from lower to higher fluid conductivity occurs at the 119-ft zone.

The well is suspected of being contaminated by road salt because it is located close to Shenandoah Road, near the crest of a steep hill. A chloride log collected under ambient conditions shows that dissolved chloride concentrations were high, about 740 milligrams per liter $(\mathrm{mg} / \mathrm{L})$, from the surface casing down to the $200-\mathrm{ft}$ zone, after which concentrations decreased with depth to about $8.5 \mathrm{mg} / \mathrm{L}$, thus seeming to confirm the presence of road salt in shallow groundwater at this location. Two point samples, collected at 180 and $260 \mathrm{ft}$ under ambient conditions, yielded chloride concentrations of 734 and $8.46 \mathrm{mg} / \mathrm{L}$, respectively, and were used to calibrate the chloride logs. Moreover, a downhole grab sample collected by GSC at $197 \mathrm{ft}$ had a dissolved sodium concentration of 199 $\mathrm{mg} / \mathrm{L}$ and a dissolved calcium concentration of $61.8 \mathrm{mg} / \mathrm{L}$, both indicators of the presence of sodium chloride and calcium chloride salts used in road salting applications (GSC, written commun., 2008).

Flow measurements at 21 locations under ambient conditions reveal a slight downward flow with a small increase from the 86- and 119-ft fractures; the downward flow exited at the $200-\mathrm{ft}$ zone. At greater depth within the borehole, the ambient flowmeter log shows upward flow emanating from the $362-\mathrm{ft}$ fracture, an additional inflow from the 323 - $\mathrm{ft}$ fracture, a slight loss of water to the 233 - $\mathrm{ft}$ fracture, and finally all of the upward flow exiting at the $200-\mathrm{ft}$ fracture. This condition is known as convergent wellbore flow. The ambient flowmeter $\log$ shows no measurable flow from $362 \mathrm{ft}$ to the bottom of the hole. Pumping the borehole at $1.2 \mathrm{gal} / \mathrm{min}$, reverses the downward flow, and the pumped-well flowmeter log indicates upward flow starting at the $362-\mathrm{ft}$ zone, a substantial inflow from the 323-ft zone, small losses to the 233- and 200-ft zone, and finally small inflows from the 119- and $86-\mathrm{ft}$ zones. The estimated fractures transmissivities are $3.9 \mathrm{ft}^{2} / \mathrm{d}$ for the $86-\mathrm{ft}$ zone, $4.8 \mathrm{ft}^{2} / \mathrm{d}$ for the $200-\mathrm{ft}$ zone, $7.9 \mathrm{ft}^{2} / \mathrm{d}$ for the $323-\mathrm{ft}$ zone, and $14.5 \mathrm{ft}^{2} / \mathrm{d}$ for the $362-\mathrm{ft}$ zone. The transmissivities for the zones at 119 and $233 \mathrm{ft}$ could not be determined but likely are less than $0.2 \mathrm{ft}^{2} / \mathrm{d}$. The estimated heads at each individual zone indicate the lowest head occurred at the $200-\mathrm{ft}$ zone with higher heads above at the 86- and 119 -ft zones and lower heads at the 323- and 362-ft zones. The head differences estimated through flow analysis generally were consistent with those measured following installation of the multiple discretemonitoring system in the test well. 

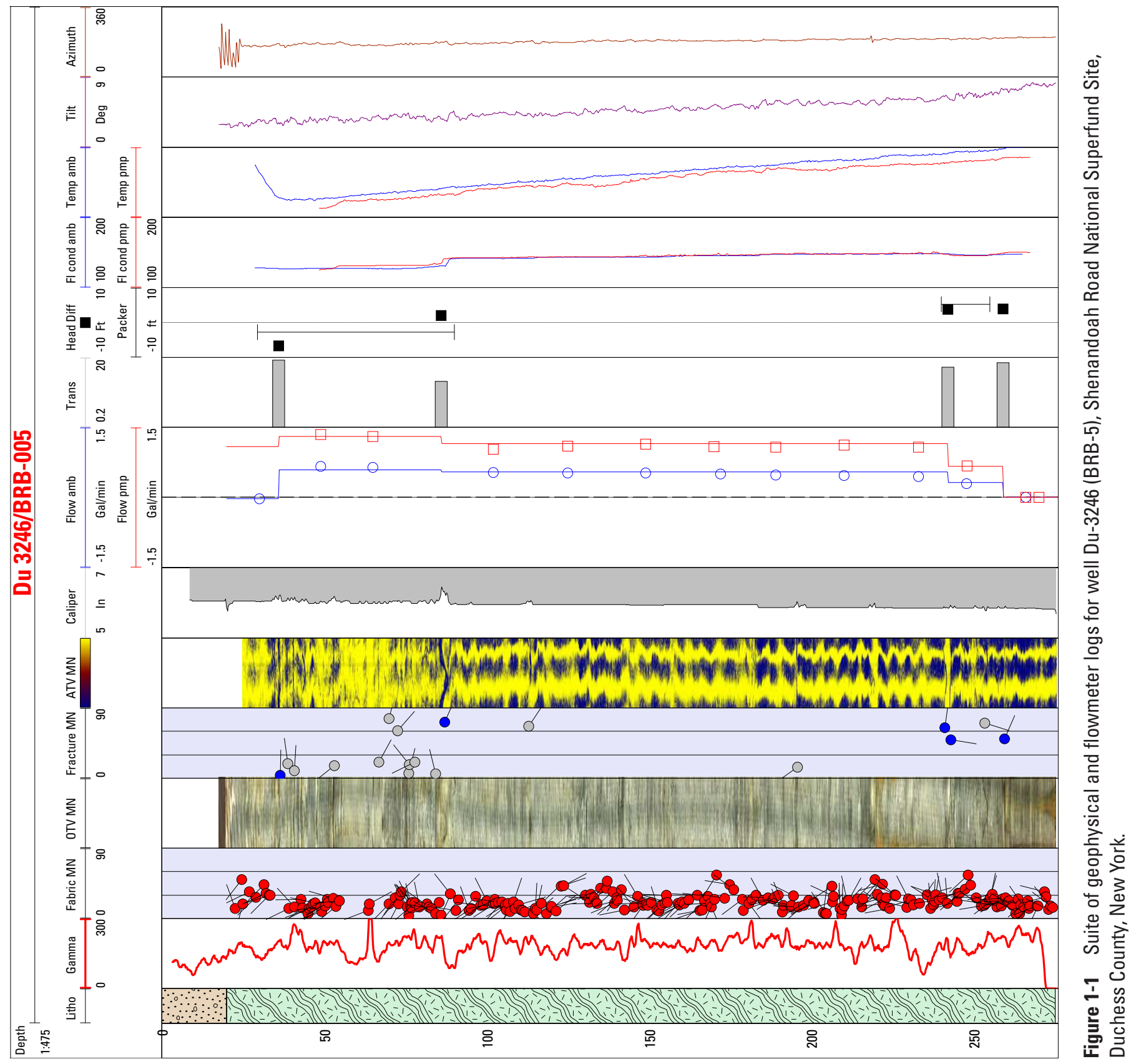


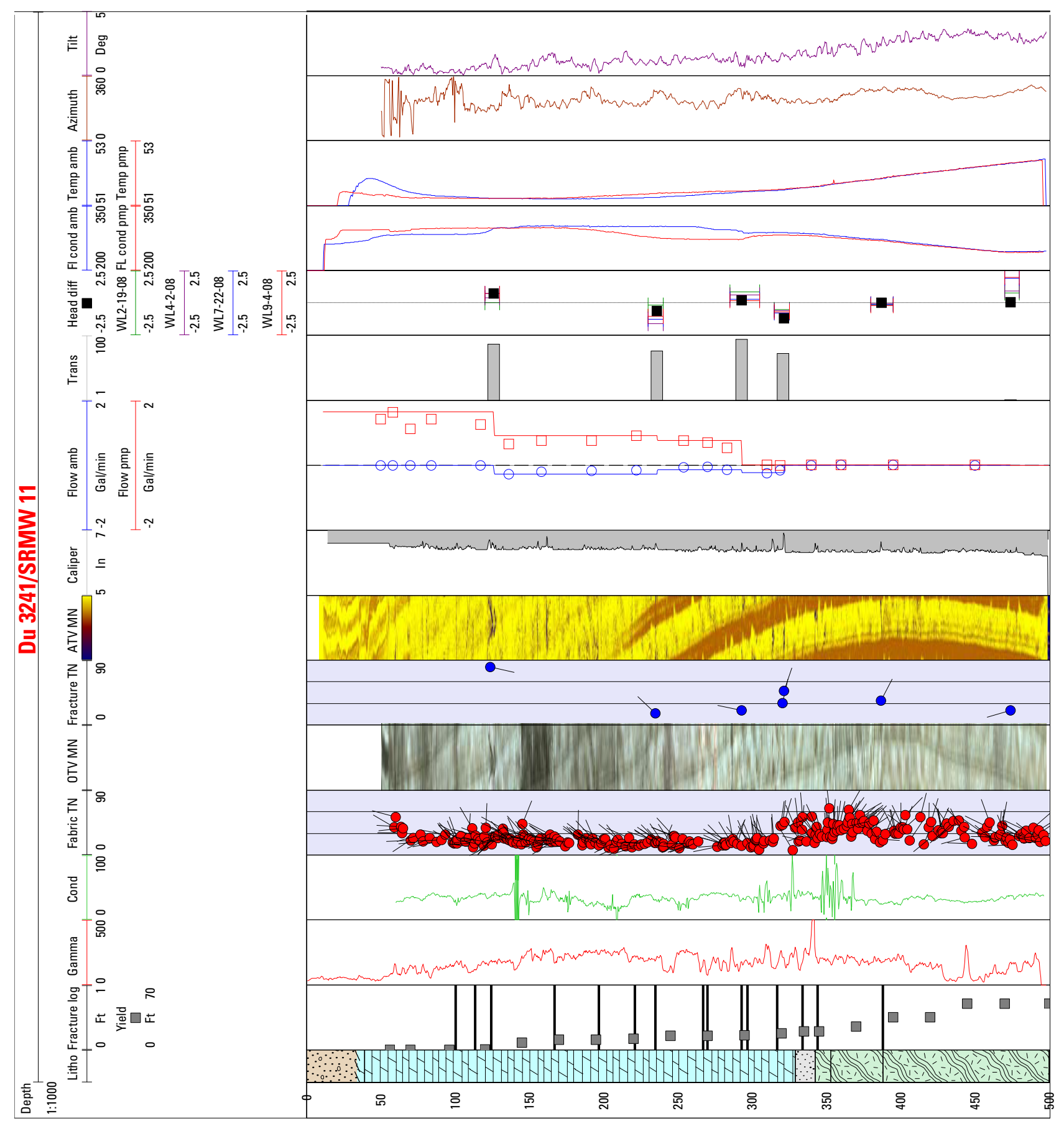




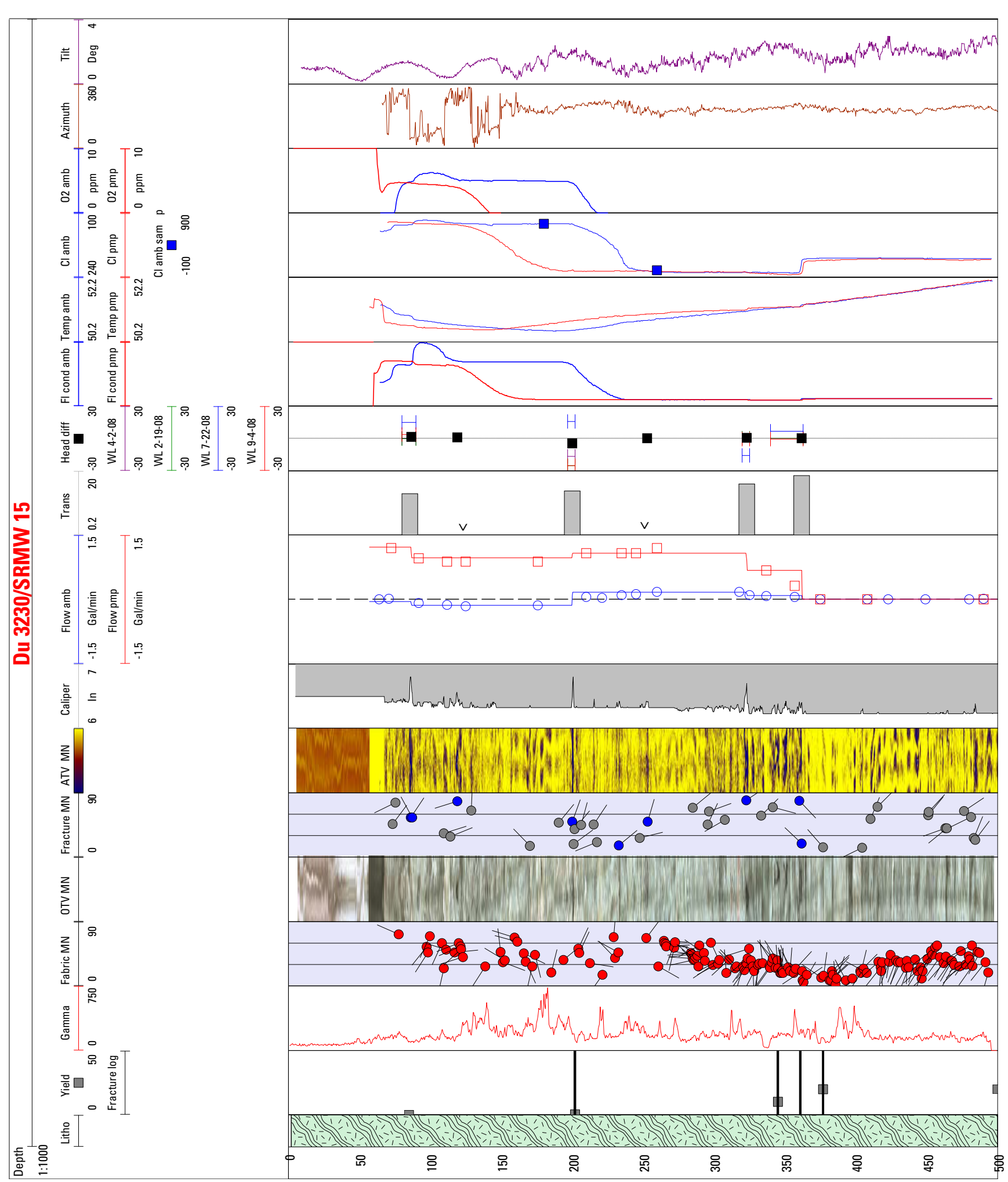




\section{Explanation of Geophysical Log Column Headings}

Du 3230/SRMW 15 U.S. Geological Survey well number/Site well number

Depth Depth, in feet below land surface

Litho Lithology; light green with dash and wavy line pattern indicates gneiss, white with stipple and dash pattern indicates quartzite, green with horizontal and angled line pattern indicates dolomite, and brown stipple and circle pattern indicates sand and gravel

Yield Cumulative blown yield reported during drilling, in gallons per minute (gal/min)

Fractured Zone Fractured zone reportedly penetrated during drilling

Gamma Gamma radiation, in counts per second

Cond Electromagnetic induction conductivity, in millisiemens per meter $(\mathrm{mS} / \mathrm{m})$

Tadpole Fabric TN Tadpole plot of foliation or bedding oriented to True Geographic North, body of tadpole indicates dip angle and tail indicates dip direction

Stereo Fabric TN Lower-hemisphere, Schmidt stereo plot of foliation or bedding oriented to True Geographic North

OTV MN Optical televiewer; 360-degree optical image of borehole wall oriented to Magnetic North

Tadpole Fracture TN Tadpole plot of planar fracture oriented to True Geographic North, body of tadpole indicates dip angle and tail indicates dip direction; blue color indicates transmissive fracture based on flow-log analysis

Stereo Fracture TN Lower-hemisphere, Schmidt stereo plot of planar fracture oriented to True Geographic North; blue color indicates transmissive fracture, based on flow-log analysis

ATV MN Acoustic televiewer; 360-degree acoustic image of borehole wall oriented to Magnetic North

Caliper Caliper; borehole diameter, in inches

Flow amb/pmp Flow, in gallons per minute; blue circle indicates ambient flow measurement with heat-pulse or electromagnetic flowmeter at specified depth; blue line indicates ambient flow based on flow-log analysis; red box indicates pumped flow measurement collected with heat-pulse or electromagnetic flowmeter at specified depth; red line indicates pumped flow based on flow-log analysis

Trans Estimated transmissivity of flow zone based on flow$\log$ analysis, in feet squared per day

Head Diff 9-4-08 Difference between flow-zone head and composite head on indicated date, in feet; black square indicates estimated head difference based on flow-log analysis; variously colored segments indicate measured head difference from discrete-zone monitoring installation
FI cond amb/pmp Fluid conductivity, in microsiemens per centimeter $(\mu \mathrm{S} / \mathrm{cm})$; blue line indicates ambient and red line indicates pumped

Temp amb/pmp Temperature, in degrees Fahrenheit; blue line indicates ambient and red line indicates pumped

$\mathbf{C l}$ amb/pmp Dissolved chloride concentration, in milligrams per liter $(\mathrm{mg} / \mathrm{L})$; blue line indicates ambient and red line indicates pumped; blue square indicates point sample

$02 \mathrm{amb} / \mathrm{pmp}$ Dissolved oxygen concentration, in milligrams per liter $(\mathrm{mg} / \mathrm{L})$; blue line indicates ambient and red line indicates pumped

Azimuth MN Direction of borehole deviation, in degrees from Magnetic North

Tilt Angle of borehole deviation, in degrees from vertical 
Prepared by the Pembroke Publishing Service Center.

For more information concerning this report, contact:

\section{Director}

New York Water Science Center

U.S. Geological Survey

425 Jordan Road

Troy, NY 12180-8349

dc_ny@usgs.gov

or visit our Web site at:

http://ny.water.usgs.gov 


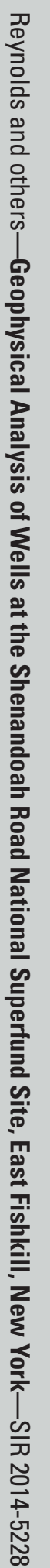

